\title{
Permafrost and hydrology in the source area of the Yellow River
}

\author{
Norikazu Matsuoka ${ }^{1}$, Atsushi Ikeda ${ }^{1}$, Tetsuo Sueyoshi ${ }^{2}$ and Takemasa Ishii ${ }^{3}$
}

Norikazu Matsuoka, Atsushi Ikeda, Tetsuo Sueyoshi and Takemasa Ishii (2009) Permafrost and hydrology in the source area of the Yellow River. Bull. Geol. Surv. Japan, vol. 60 (1/2), p. 39-57, 15 figs, 1 table.

\begin{abstract}
Frozen ground was investigated in 2003-2006 to evaluate the present-day distribution and ongoing degradation of permafrost in the source area of the Yellow River, located at the northeastern margin of the Tibetan Plateau. The presence of permafrost was examined by seismic, electrical and/ or thermal soundings at 18 sites between $3,250 \mathrm{~m}$ and 4,800 $\mathrm{m}$ a.s.1. Then, permafrost distribution fitted to the sounding results was mapped by means of GIS. Temporal variations in ground thermal and hydrological regimes were also investigated for two years at Madoi observatory (4,273 m a.s.1.), by automatic and manual observations of air and ground ( $0-8 \mathrm{~m}$ deep) temperatures, precipitation, snow depth, near-surface soil moisture and groundwater level. In addition, numerical simulation of the ground thermal profiles was performed to discuss the degree of permafrost degradation under the observed atmospheric warming.

High P-wave velocities $(>2 \mathrm{~km} / \mathrm{s})$ and relatively high DC resistivities $(650-1,100 \Omega \mathrm{m})$ below a thin uppermost layer show that permafrost $10-30 \mathrm{~m}$ in thickness occurs above $4300 \mathrm{~m}$ a.s.1. In contrast, low P-wave velocities $(<1 \mathrm{~km} / \mathrm{s})$ throughout the sediments indicate that permafrost is absent below 4,000 $\mathrm{m}$ a.s.1. On widespread alluvial plains between 4,200 $\mathrm{m}$ and 4,300 $\mathrm{m}$ a.s.1., permafrost is lacking or significantly degraded. Negative values of the mean annual ground surface temperature (MAST) also indicate widespread permafrost only above $4,300 \mathrm{~m}$ a.s.l. under the present climatic condition. The seasonal frost penetration reachs a maximum depth of $2.6 \mathrm{~m}$ at the observatory. Intermittent and very shallow snow cover favor frost penetration. The ground between $4 \mathrm{~m}$ and $8 \mathrm{~m}$ in depth was kept at slightly positive temperatures $\left(0-4{ }^{\circ} \mathrm{C}\right)$ throughout two years, although the presence of permafrost at this site was suggested by a few reports in the 1980s. Assuming that the inter-annual variation in MAST follows that in the mean annual air temperature, permafrost is estimated to have significantly thawed on the alluvial plains at 4,200-4,300 $\mathrm{m}$ a.s.l. during the last half-century. The numerical simulation suggests that thin $(<15 \mathrm{~m})$ permafrost can significantly degrade within this time scale. The resulting degradation of the permafrost is assumed to have extended $3,000 \mathrm{~km}^{2}$ on the alluvial plains in the source area.
\end{abstract}

Keywords: Permafrost, Yellow River, Qinghai Province, Tibetan Plateau, Madoi, seismic sounding, geoelectrical sounding, thermal monitoring, numerical simulation, degradation

\section{The significance of permafrost in high mountain hydrology}

Global warming has a significant impact on the cryosphere, where surface ice (glaciers) or subsurface ice (ground ice/permafrost) directly responds to climate change (e.g., Lachenbruch and Marshall, 1986; Osterkamp and Romanovsky, 1999; Harris et al., 2003). Permafrost widely occurs from high-latitude lowlands to mid-latitude high mountains. The former areas are subdivided into the continuous permafrost areas, where permafrost is thick $(>100 \mathrm{~m})$, cold (mostly $<-2{ }^{\circ} \mathrm{C}$ ), and continuous, and the discontinuous permafrost areas, where permafrost is thin $(<100 \mathrm{~m})$, warm $(>-2$ ${ }^{\circ} \mathrm{C}$ ), and dependent on vegetation, snow cover, slope aspect, and the presence of surface water. Permafrost is invisible on the ground surface, because it is overlain by a seasonally thawed layer (the active layer) whose thickness is usually less than $3 \mathrm{~m}$ and variable with the summer temperature. Beyond the southern margin of the discontinuous permafrost area (in the case of the Northern Hemisphere), permafrost occurs sporadically

\footnotetext{
${ }^{1}$ Graduate School of Life and Environmental Sciences, University of Tsukuba

${ }^{2}$ Center for Climate System Research, University of Tokyo

${ }^{3}$ AIST, Geological Survey of Japan, Institute for Geo-Resources and Environment
} 
on high mountains such as Tibet-Himalaya, Alps, and Rockies, and called the mountain (or alpine) permafrost. The mountain permafrost is generally thin and warm, and its distribution is strongly affected by the slope aspect (incoming radiation) and snow cover (thermal insulator). These permafrost areas are surrounded by the seasonal frost areas, where permafrost is absent but cold winter and paucity of snow cover combine to produce a deep seasonally frozen layer with a thickness up to $3 \mathrm{~m}$.

In eastern Asia, permafrost widely occurs from Siberian lowlands to Mongolian mountains (continuous/ discontinuous permafrost) and Tibetan Plateau (mountain permafrost), reflecting continental dry-cold climate. Recently, however, warm permafrost (thickness less than several decameters and temperature close to $0{ }^{\circ} \mathrm{C}$ ) have rapidly been thinning or even disappearing from the marginal permafrost areas (e.g., Sharkhuu, 1998; Jin et al., 2000).

The source area of the Yellow River, which involves the northeastern part of the Tibetan (QinghaiXizang) Plateau, is also widely underlain by perennially or seasonally frozen ground (e.g., Zhou et al., 2000). The presence and temporal variation of the frozen ground control the groundwater regime, lake levels, and water input to streams, because the near-surface impermeable layer, especially permafrost, maintains a shallow groundwater level but its degradation allows deep percolation of subsurface water. Degradation of permafrost may thus significantly influence water resources in the drainage basin. In fact, recent studies have emphasized rapid degradation of permafrost and associated lake shrinkage, decreasing river discharge, lowering groundwater level, and changing vegetation on the eastern Tibetan Plateau (e.g., Wang et al., 2001; Peng et al., 2003; Zhang et al., 2004; Böhner and Lehmkuhl, 2005; Feng et al., 2006).

Since 2002, the frozen ground research group has investigated the distribution and dynamics of frozen ground and their impact on hydrology in the source area (Fig. 1). The field investigations include automatic monitoring of frozen ground regimes at Madoi and geophysical (seismic and geoelectrical) sounding of subsurface water and frozen ground at a number of localities in the source area that belongs to the Qinghai Province (e.g., Ikeda et al., 2004, \& 2007; Matsuoka et al., 2004, 2005, \& 2006). These field results were incorporated in GIS to produce permafrost maps and in modeling of a temporal change in permafrost distribution. The study area comprises a plateau with elevations of over 3,500 $\mathrm{m}$ a.s.1., where dry climate and

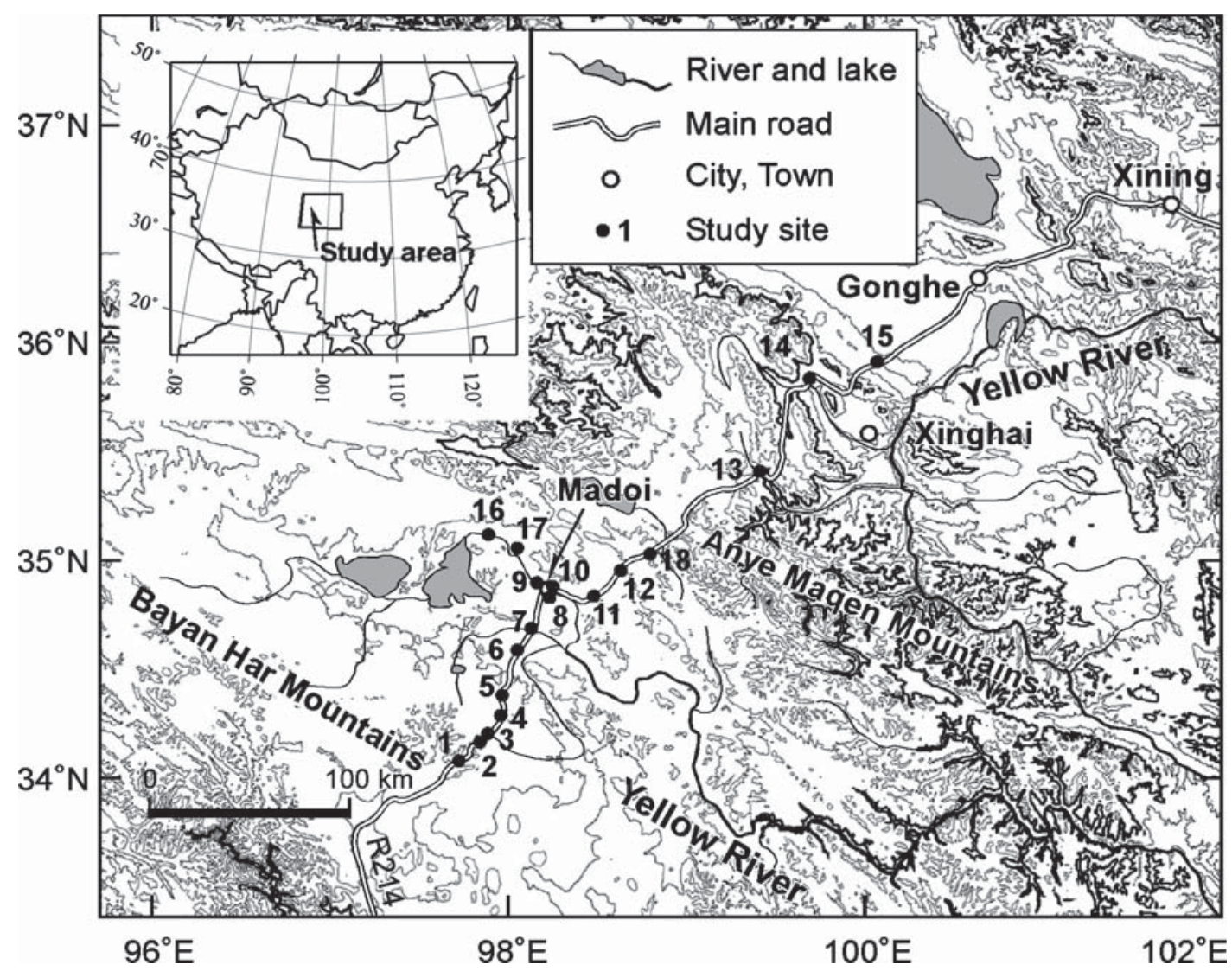

Fig. 1 Location map. 
a lack of higher terrain combine to restrict glaciers to develop on only a few mountains above 5,000 $\mathrm{m}$ a.s.1. (Wang and Derbyshire, 1987; Owen et al., 2003). The land surface above the timberline at about 3,600 m a.s.l. is dominated by grassland (alpine meadow) that has been subjected to widespread grazing activity and partly occupied by wetlands and lakes.

\section{Automatic monitoring of frozen ground at Madoi}

\subsection{Site and instrumentation}

The Madoi observatory is located at the Madoi meteorological station $\left(98^{\circ} 13^{\prime} \mathrm{E}, 34^{\circ} 55^{\prime} \mathrm{N}, 4,273 \mathrm{~m}\right.$ a.s.1.: Site 10 in Fig. 1), the elevation of which representing the surrounding plateau area $(4,200-4,300 \mathrm{~m}$ a.s.1.). The meteorological records in 2001-2006 indicate that the Madoi region experiences a cold-dry climate, with a mean annual air temperature (MAAT) of $-1.8{ }^{\circ} \mathrm{C}$, a large annual thermal amplitude ranging from $-13.0^{\circ} \mathrm{C}$ in January to $9.4{ }^{\circ} \mathrm{C}$ in July, and an annual precipitation of $310 \mathrm{~mm}$ (after the Weatheronline homepage: www. t7online.com). The MAAT represents a marginal value for the presence of permafrost. Precipitation concentrated in summer months (May-October), while less than $10 \%$ of the annual amount falls in the rest of a year. The latter leads to only ephemeral and shallow snow cover. These conditions provide a deep active layer where permafrost is present or a deep seasonally frozen layer where permafrost is absent. Temperature records show that MAAT rose by $2.3{ }^{\circ} \mathrm{C}$ compared with the mean value for 1953-1980 (Zhou et al., 2000), suggesting significant warming and degradation of permafrost within a few decades.

Sediments derived from a $10 \mathrm{~m}$ deep borehole (drilled on 11 August 2004) displayed the near-surface stratigraphy. The uppermost $2.4 \mathrm{~m}$ consists of sandy silt lacking stones, which probably represents loess. Below the topsoil, the material is gravelly to the bottom of the borehole but mostly supported with sandy or silty matrix, which was probably of a fluvial origin. During the drilling, no core was obtained at frozen state, although the material below $7 \mathrm{~m}$ depth was hard and compact.

A CR10X logger (manufactured by Campbell Scientific, USA) recorded environmental parameters at hourly intervals (Fig. 2). Platinum probes sensed air temperature (with a ventilated radiation shield) at 1.65 $\mathrm{m}$ above the ground surface and ground temperature at depths of $0.03,0.3,1.3,2.3,4.3,6.3$, and $7.8 \mathrm{~m}$. An ultrasonic transducer detected the snow depth. TDR (Time Domain Reflectometry) sensors recorded the volumetric water content of soil at $0.3,0.6$, and $0.9 \mathrm{~m}$ depths. Thermal properties (conductivity, diffusivity, and heat capacity) were also measured at $0.1 \mathrm{~m}$ depth. A solar panel constantly provided the electricity to the data logger. The logging started at $1,500 \mathrm{~h}$ on 12 August 2004 and provided continuous data until 1,000 h on 3 August 2006. Manual observations at the Madoi observatory also provided data on the daily precipitation

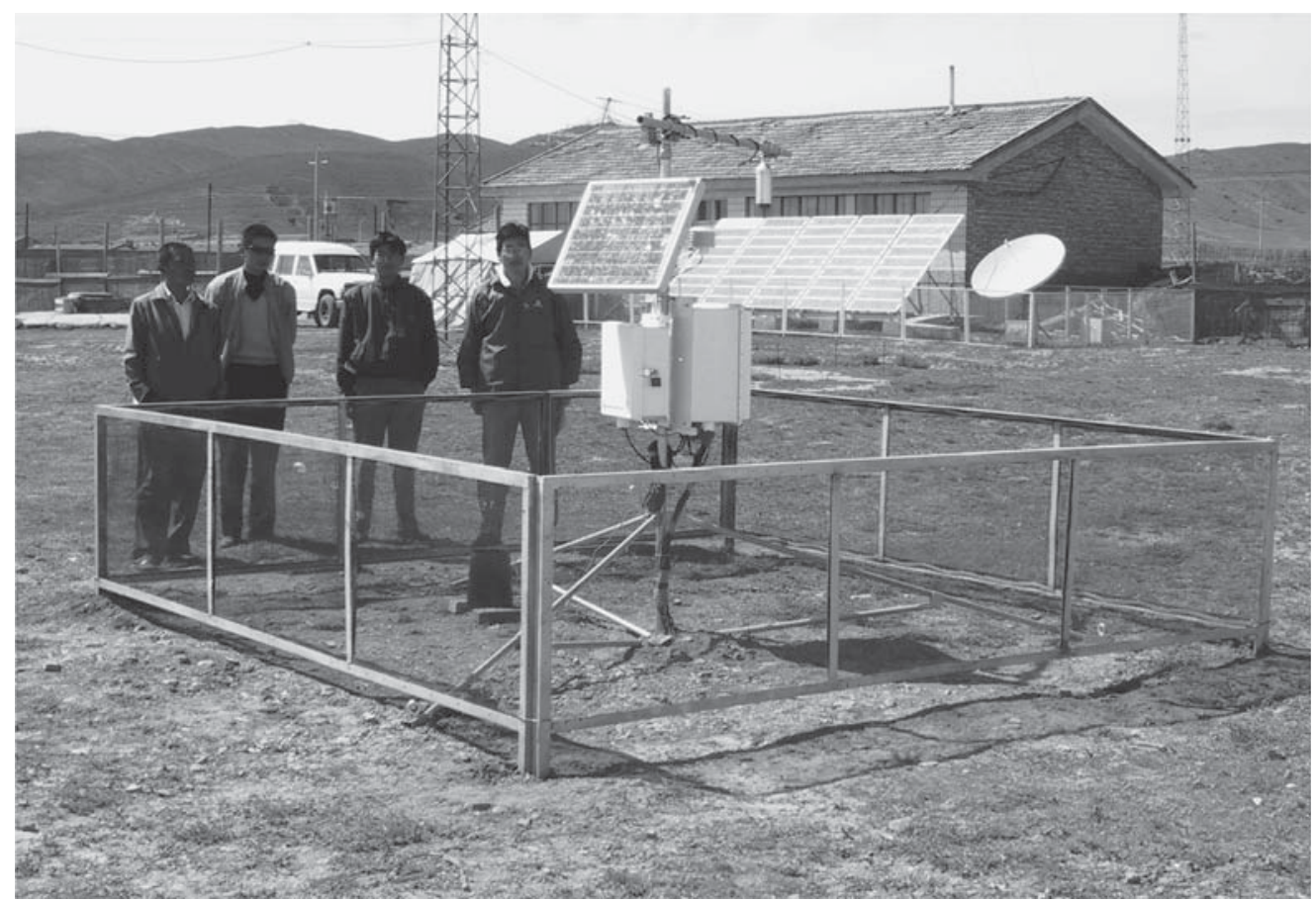

Fig. 2 The Madoi observatory and instruments. The Madoi meteorological station on the back. 
and weekly groundwater level.

\subsection{Results and interpretations}

Figure 3 summarizes two years of thermal and hydrological data at the observatory. Data on the snow depth indicate the occurrence of shallow and ephemeral snow cover during the two years. Snow cover lasting for more than two days occurred only five times. The maximum snow depth was $8 \mathrm{~cm}$ in the first winter (2004-2005) and $4 \mathrm{~cm}$ in the second winter (2005-2006). An extraordinarily deep snow cover (up to $40 \mathrm{~cm}$ ) on 22 and 23 May 2005 coincided with nocturnal negative temperatures and a significant precipitation event ( $8.7 \mathrm{~mm}$ for two days), implying the occurrence of snowfall. However, the records may have included some noises, since they indicated that snow accumulated and disappeared within 12 hours.

The general lack of winter snow cover led to large diurnal fluctuations in the ground surface temperature throughout the year (Fig. 3). A high correlation $\left(\mathrm{R}^{2}=\right.$ $0.95)$ was found between the daily mean air temperature $\left(T_{a}\right)$ and the daily mean surface temperature $\left(T_{s}\right)$ in the second year (Fig. 4A), which reflects the snowfree ground. The two temperatures were, however, different from each other in two points. First, $T_{s}$ usually exceeded $T_{a}$ by $4.4{ }^{\circ} \mathrm{C}$ on average: MAAT was $-2.1{ }^{\circ} \mathrm{C}$ and the mean annual surface temperature (MAST) was $2.4{ }^{\circ} \mathrm{C}$ in the second year. The temperature difference is significantly larger than those in other cold regions (e.g., snow-free ground in Alaska: Zhang, 2005). Second, the magnitude of daily amplitudes showed a seasonal contrast such as $T_{s}$ ranged more widely than $T_{a}$ in summer but the relation was reversed in winter (Fig. 5B). The reversal mainly reflected the high daytime (maximum) surface temperatures in summer and low nocturnal (minimum) air temperatures in winter with reference to the other temperatures (Fig. 5A). The above two features are considered to originate from the
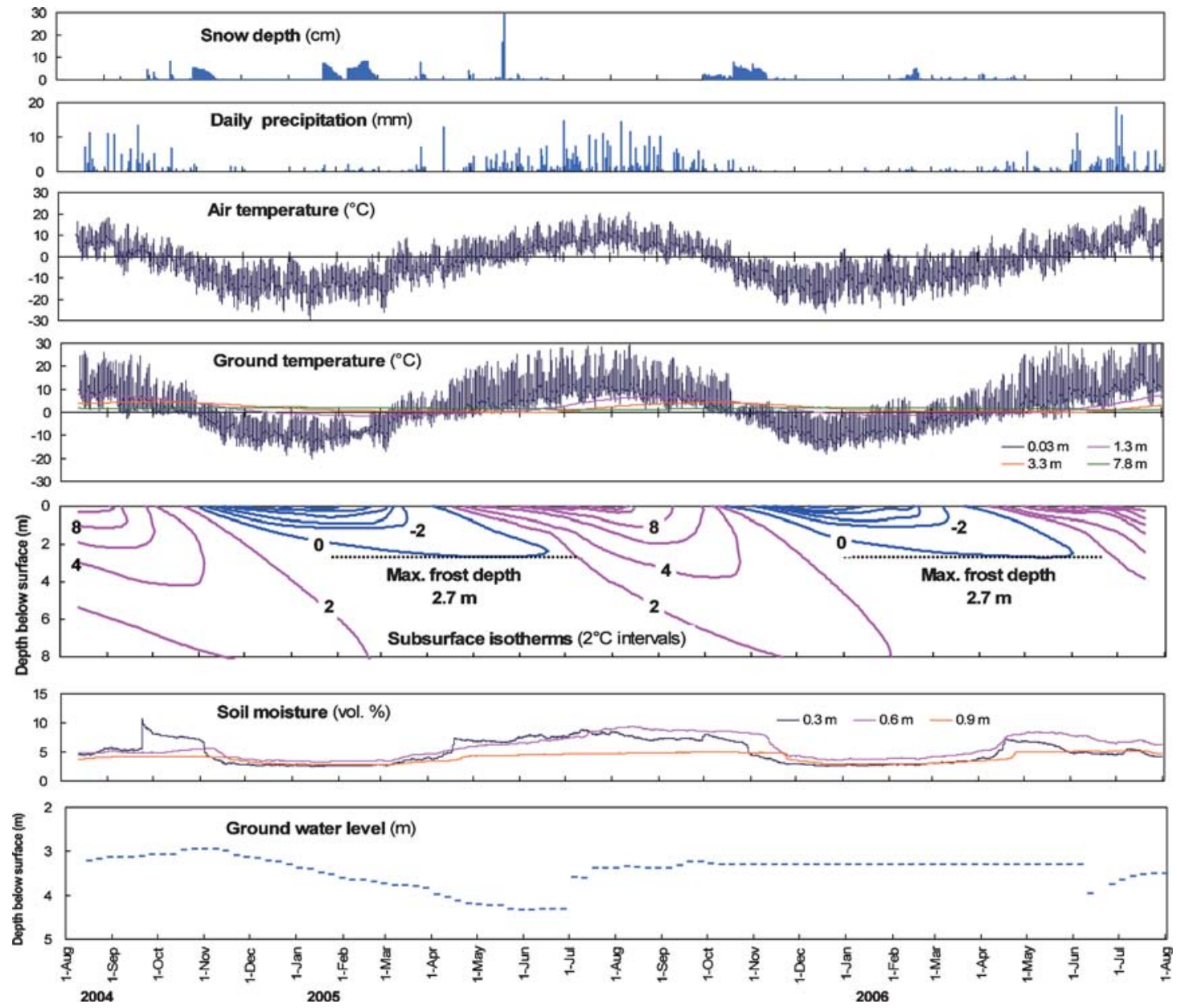

Fig. 3 Time series of environmental parameters at the Madoi observatory (2004-2006). Snow depth, air and ground temperature, and soil moisture were monitored at 1-h intervals. The isotherms were drawn on the basis of $10-\mathrm{d}$ mean ground temperatures. The groundwater level derives from weekly manual measurements. 
dry ground surface, the seasonal variation in incoming shortwave radiation which mainly depends on the Sun's altitude and daylength, and difference in air circulation. The dry ground surface experiences only minimum exchange of the latent heat, so that radiation plays a primary role in determining the surface temperature. In summertime, the long daylength enhances the strong incoming shortwave radiation, which results in high daytime surface temperature, whereas the air warmed up by the longwave radiation from the ground maintains relatively low temperature through the advection and convection. In wintertime, cold air may flow down to
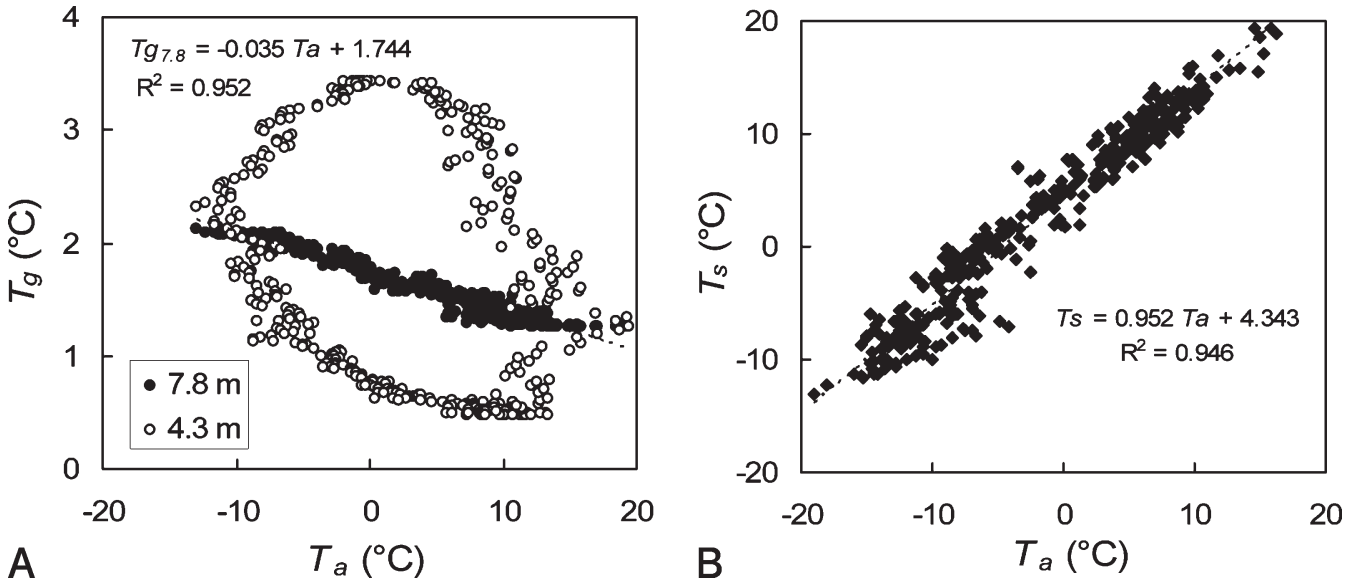

Fig. 4 Relationships between air and ground temperatures for the second year (1 August 2005-31 July 2006). A. Mean daily air temperatures $\left(T_{a}\right)$ versus ground surface (at $3 \mathrm{~cm} \mathrm{depth}$ ) temperatures $\left(T_{s}\right)$. B. Mean daily air and ground temperatures $\left(T_{g}\right)$ at $4.3 \mathrm{~m}$ and $7.8 \mathrm{~m}$ depths.
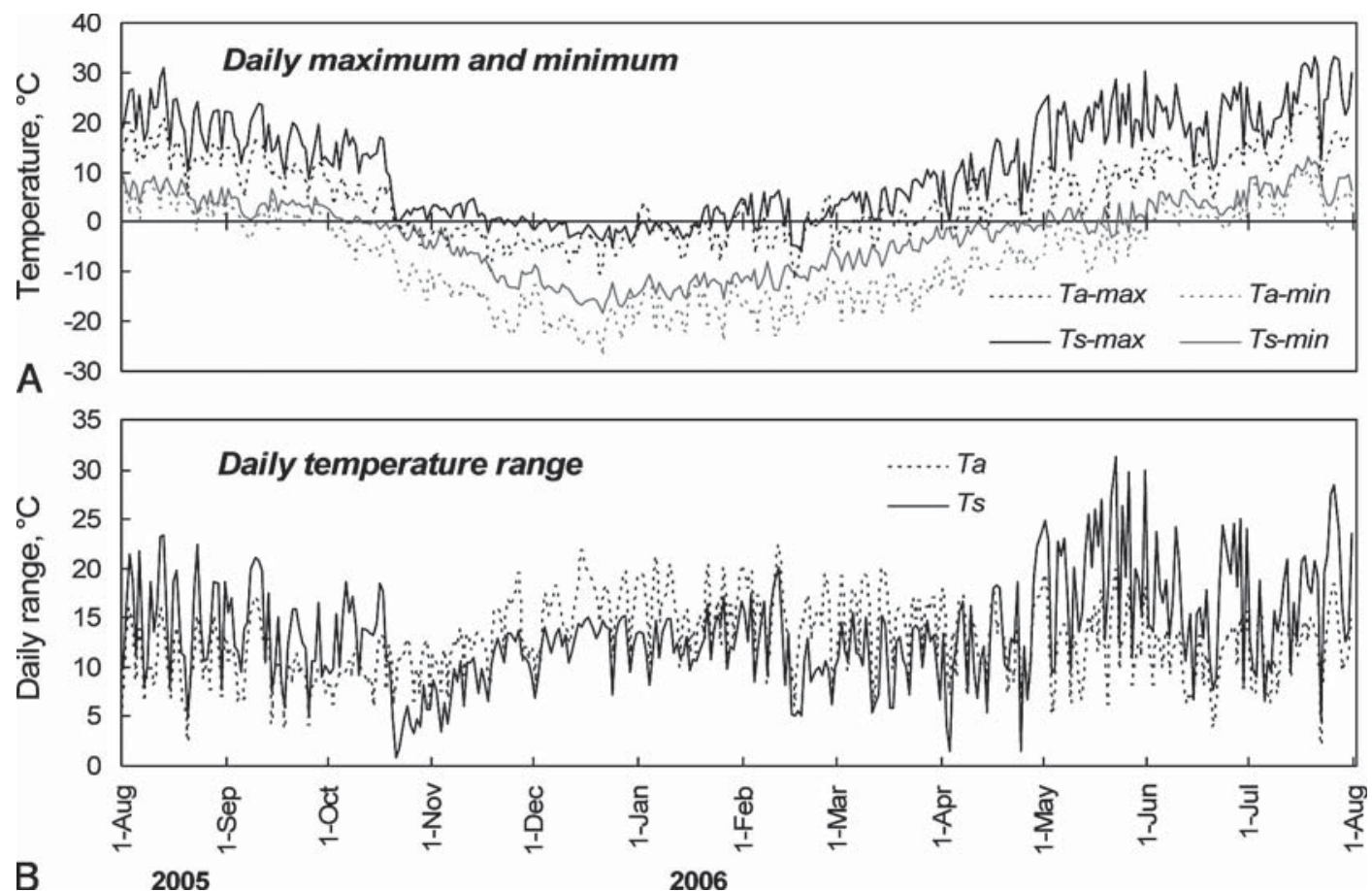

Fig. 5 Annual variations in air and ground surface temperatures in 2005-2006. A. Daily maximum and minimum temperatures. $T_{a-\max }$ : maximum air temperature; $T_{a-\min }$ : minimum air temperature; $T_{s-\max }$ : maximum surface temperature; $T_{s-m i n}$ : minimum surface temperature. B. Daily ranges for air temperature $\left(T_{a}\right)$ and surface temperature $\left(T_{s}\right)$. 
the basin from the surrounding hills, which results in the low nocturnal air temperature.

Annual variation in subsurface temperature shows reduced amplitude and a phase delay with increasing depth (Fig. 3). At Madoi, the annual temperature range in 2005-2006 was $32{ }^{\circ} \mathrm{C}$ at the surface, and the range diminished to $3{ }^{\circ} \mathrm{C}$ at $4.3 \mathrm{~m}$ depth and to $0.8^{\circ} \mathrm{C}$ at $7.8 \mathrm{~m}$ depth (Fig. 4B). The peak temperatures at $4.3 \mathrm{~m}$ depth were observed three months behind those at the surface, and the timing was even completely reversed between the surface and $7.8 \mathrm{~m}$ depth (Fig. 4B).

The lack of winter snow cover was also responsible for deep frost penetration. Seasonal freezing began in early November 2004 and in mid October 2005, and penetrated into the ground at a rate of up to $1.0 \mathrm{~m}$ per month until January. Frost penetration then decelerated and finally reached a maximum depth of $2.7 \mathrm{~m}$ in May in both years (Fig. 3). Thaw penetration began in early April 2005 and in late March 2006, and progressed at a rate of $0.7-1.0 \mathrm{~m}$ per month until the ground completely thawed in mid July 2005 and in early July 2006. Below the maximum frost depth $(2.7 \mathrm{~m})$, negative temperatures were never recorded and the mean annual ground

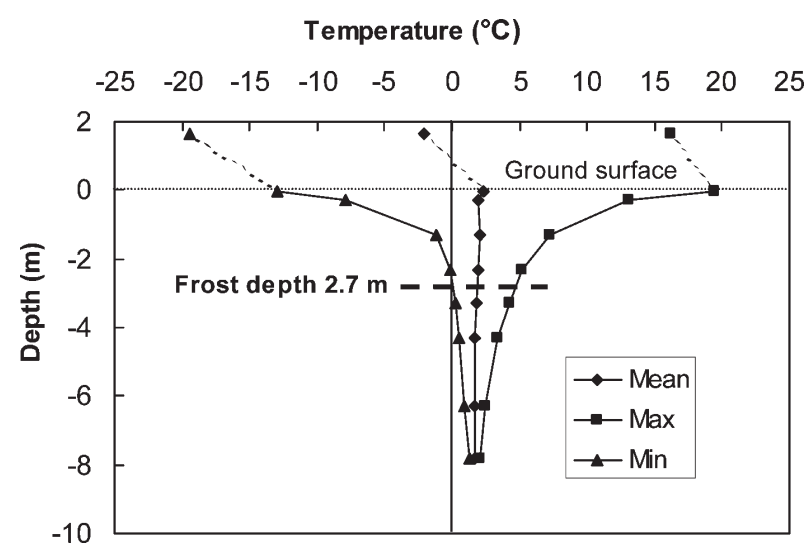

Fig. 6 Ground temperature profile in 2005-2006, indicating mean annual temperatures, maximum and minimum of mean daily temperatures, and seasonal frost depth. Air temperature at $1.65 \mathrm{~m}$ is also shown. temperature (MAGT) was uniformly $1.7-1.8{ }^{\circ} \mathrm{C}$ over 3.3-7.8 m depth (Fig. 6). Downward extrapolation of this MAGT rejects the presence of negative temperature at deeper ground. Thus, even relict permafrost is unlikely to be present below an unfrozen talik. An assumption of the concurrent rise in MAST (about 2 ${ }^{\circ} \mathrm{C}$ during the last 25 years), however, suggests the possible presence of negative MAGT (i.e., permafrost) at shallow depth a few decades ago.

The near-surface soil (30-90 cm depth) had low water content $(<10 \%$ vol.) throughout the year (Fig. 3 ). This reflected the small amounts of precipitation, the paucity of snowmelt water, and the low groundwater level $(>3 \mathrm{~m})$. The temporal variation in soil moisture basically followed the frost regime and precipitation. However, the response to precipitation events was generally slow and the short-term precipitation rarely affected soil moisture below $30 \mathrm{~cm}$ depth. A significant change happened when the freezing (or thawing) front reached, basically reflecting the liquid water content (e.g., Stein and Kane, 1983; Spaans and Baker, 1995). In particular, soil moisture at $30 \mathrm{~cm}$ depth rose sharply during the thawing period. After the complete thawing of the soil, the moisture variation was slightly different between the summers of 2005 and 2006. In the former, soil moisture was relatively low in the early summer and rose toward the late summer, reflecting a number of precipitation events during the early summer. In the latter, moisture was highest just after the complete thawing and gradually decreased until early July, probably reflecting the very small precipitation in May. A sudden rise recorded at $30 \mathrm{~cm}$ depth on 23 September 2004 followed precipitation (17 $\mathrm{mm}$ in 3 days), but this event may have included an error due to the initial instability of the sensor or another electrical problem.

The groundwater level also varied seasonally (Fig. 3). Having reached the highest level $(2.95 \mathrm{~m})$ in early November 2004 when seasonal frost started, the water level went down gradually with frost penetration, lying at about $1.5 \mathrm{~m}$ below the freezing front (Fig. 7). Complete thawing of the seasonal frost raised the water level by $0.7 \mathrm{~m}$ within a week in early July 2005,

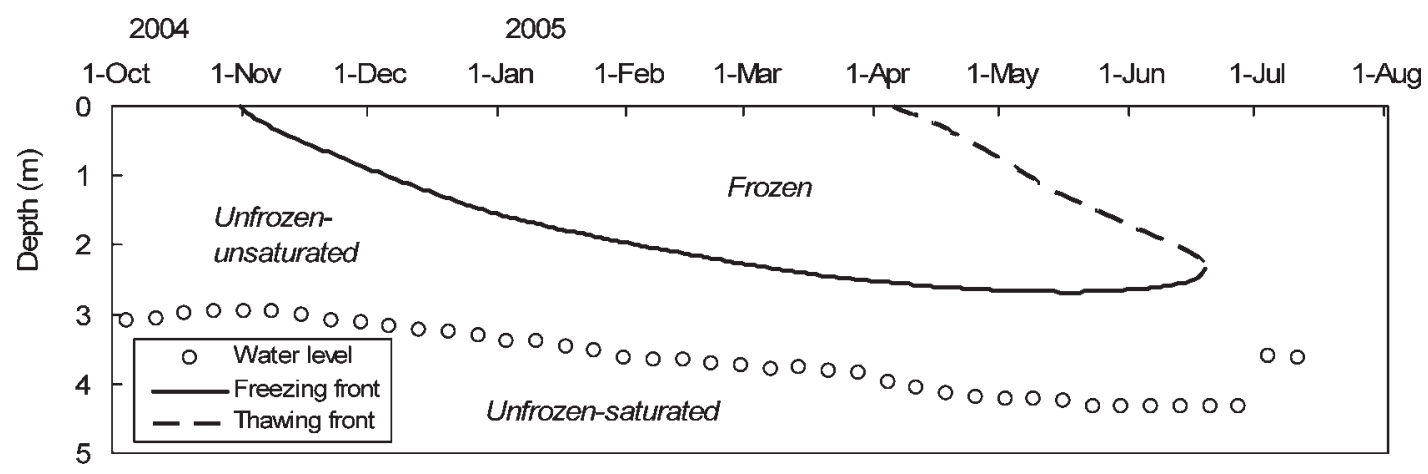

Fig. 7 Seasonal variations in frozen ground and groundwater level in 2004-2005. 
probably owing to downward percolation of both meltwater from the frozen layer and rain-induced water stored above the frozen layer. The constant water level at $3.3 \mathrm{~m}$ from October 2005 to July 2006 (Fig. 3) was unrealistic. A possibility is that a blocking ice film formed at $3.3 \mathrm{~m}$ depth in October and stayed there until thawing. Thus, in the second winter the measurement failed to represent the actual water level that must have underlain far below the assumed ice film.

\section{Distribution of permafrost}

\subsection{Methods of permafrost sounding}

The presence of permafrost was examined by refraction seismic sounding at fifteen sites (Sites 2, 4-14 and 16-18) and one-dimensional (vertical) direct current (DC) resistivity sounding at eleven sites (Sites 2 and 4-13) (Table 1 and Fig. 1). All sites except Sites 12,13 and 14 were located on flood plains with the slope gentler than $2^{\circ}$ and wider than $2 \mathrm{~km}$ underlain by fluvial sediments probably much thicker than $10 \mathrm{~m}$. Site 12 was located on a narrow flood plain $(<500 \mathrm{~m}$ wide) and Sites 13 and 14 were on terraces. The terrace scarp showed that the sediment was at least $10 \mathrm{~m}$ thick at Site 13 and more than $50 \mathrm{~m}$ thick at Site 14. Site 7 was located at a former shoreline of a recently degraded lake.

In the seismic sounding, the receiver of the McSEIS-3 seismograph (Oyo, Japan) sensed seismic pulses produced at $2.5-5 \mathrm{~m}$ intervals along a $30-50$ $\mathrm{m}$ long survey line by a sledgehammer. The P-wave velocities of two or three layers and the depth(s) of layer boundaries were determined using the intercept time method (Palmer, 1986). The reciprocal method (Palmer, 1986) was employed to obtain more accurate P-wave velocities of the second layer at Sites 4, 10, 11, and 12, where a pair of travel time curves (i.e., forward and reverse arrival times measured on one survey line) was obtained. The soundings were carried out in late August 2003, mid August 2004, and early August 2006.

The DC resistivity sounding was performed at 11 sites on early July 2005 with the SYSCAL R1 PLUS resistivity meter (Iris Instruments, France). The setting of the electrodes followed the Schlumberger array. The length of a sounding profile varied from 200 $\mathrm{m}$ to $400 \mathrm{~m}$ at each site. Modeled resistivity curves fitting with measured values were calculated with WinSev6 software (W_GeoSoft, Switzerland). First, the resistivities and boundary depths of subsurface layers were manually determined by fitting standard and auxiliary curves. Second, the initial values were automatically adjusted to measured resistivities by the least squares method (Koefoed, 1979). Where seismic data were available, boundary depths of resistivity layers were fixed to the nearby boundary depths of P-wave stratigraphies.
Thermal monitoring was also performed at eleven sites. Year-round ground surface temperatures were recorded at hourly intervals with a miniature data logger TR-51A (T \& D, Japan). A logger placed beneath a platy stone measured temperature at 3-4 $\mathrm{cm}$ depth at eight sites (Sites 1, 3, 4, 7, 11, 13, 14, and 15) between 4,790 $\mathrm{m}$ and 3,260 $\mathrm{m}$ a.s.l. from mid August 2003 (Fig. 1 and Table 1). The logger at Site 15 was moved to Site 6 in mid July 2005. At the same time, a two-channel data logger H08-031-08 (Onset Computer, USA) was placed on Sites 5 and 9. The two-channel logger recorded temperature at surface $(5 \mathrm{~cm}$ depth) and 60 $\mathrm{cm}$ depth bihourly. All sites were located on flat terrain lacking shading topography and vegetation.

Mean annual ground surface temperature (MAST) is a useful indicator of permafrost (Ikeda, 2006). Under stable climate, the upward geothermal heat flow leads to the lowest mean annual ground temperature (MAGT) at the surface. Thus, a negative MAST is required for the presence of permafrost at a few meters depth. In reality, however, the climatic warming has gradually reversed the near-surface MAGT profile (e.g., Lunardini, 1996). Thus, degrading permafrost is likely present even under a slightly positive MAST (e.g., Ikeda and Matsuoka, 2002). MASTs were computed from surface temperature data for 365 days.

To test the interpretation of sounding results, the near surface stratigraphy of the flood plains was directly observed with the cores recovered from a $6 \mathrm{~m}$ deep borehole at Site 9 (drilled on 12 August 2004) and from a $10 \mathrm{~m}$ deep borehole at Site 10 (i.e., the Madoi observatory).

\subsection{Results and interpretation of seismic sounding}

The travel time curves of $\mathrm{P}$-wave velocities are classified into three types. The first type shows a sharp break in a velocity profile within $10 \mathrm{~m}$ in distance from the receiver (Sites 2, 4, 5, 7, 8, 10, 11, 12, 17, and 18). The second type shows more gentle two breaks in a velocity profile indicating three layers (Sites 6, 9, 13, and 16). The third type shows a nearly constant velocity (Site 14). The first layer of all curves has a velocity of $0.35-0.49 \mathrm{~km} \mathrm{~s}^{-1}$ (Table 1). The first and second types show a subsurface layer with a high velocity of 1.5-3.4 $\mathrm{km} \mathrm{s}^{-1}$. The upper surface of each high velocity layer of the first type lies at 2-4 m depth, whereas that of the second type lies below a depth of $8 \mathrm{~m}$. A velocity of $0.71-0.99 \mathrm{~km} \mathrm{~s}^{-1}$ was calculated for the second layer of Sites 2, 6, 9, 13, 14, and 16 .

$\mathrm{P}$-wave velocities lower than $1 \mathrm{~km} \mathrm{~s}^{-1}$ indicate unconsolidated and unsaturated materials (Milsom, 2003). The subsurface high velocities correspond to the values for various types of permafrost $\left(1.5-4.7 \mathrm{~km} \mathrm{~s}^{-1}\right.$ : Hunter, 1973). Within this velocity range, relatively high velocities at Sites 2, 4, 5, 6, 8, 11, 12, 13, 16, 17, and $18\left(2.2-3.4 \mathrm{~km} \mathrm{~s}^{-1}\right)$ are also equivalent to velocities 


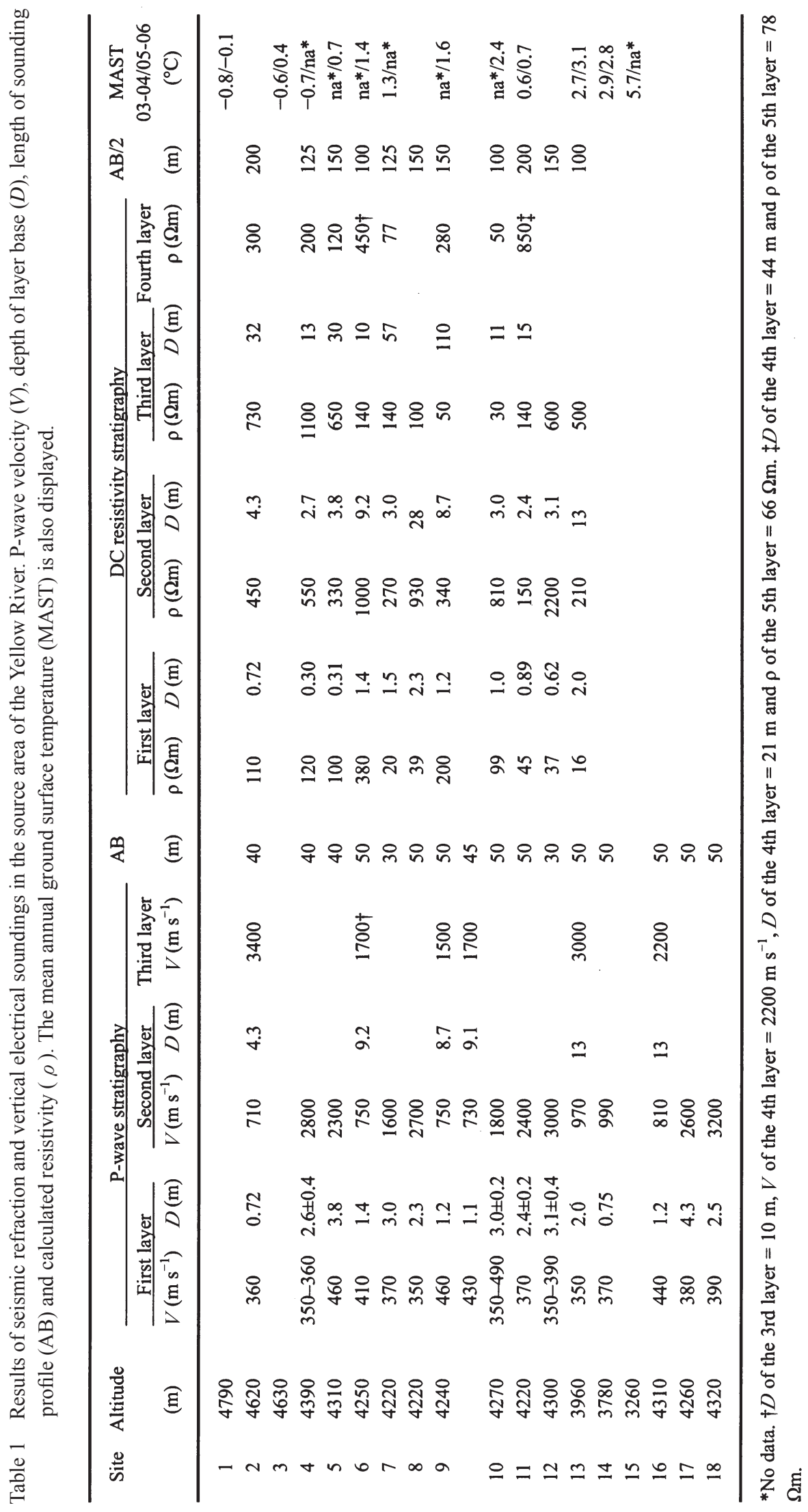


of sandstone and shale bedrock, and relatively low velocities observed at Sites 7, 9, and $10\left(1.5-1.8 \mathrm{~km} \mathrm{~s}^{-1}\right)$ to velocities of unfrozen saturated sediments (Milsom, 2003). In the former case, if the upper surface of the high velocity layer is too shallow to be bedrock, the high velocity layer is regarded as frozen sediment. Thus, the thin low-velocity top layer (2-4 m thick) at Sites 2, 4, $5,8,11,12,17$, and 18 indicates the presence of frozen ground above 4,200 $\mathrm{m}$ a.s.1. Three sites between 4,200 $\mathrm{m}$ and 4,300 $\mathrm{m}$ a.s.1. (Sites 6, 13, and 16) probably have frozen sediment below an unfrozen layer about $10 \mathrm{~m}$ thick, which indicates that the frozen layer is obviously degrading permafrost (i.e., relict permafrost). Locations below 4,000 m a.s.1. (Sites 13 and 14) lack a nearsurface high velocity layer (Table 1). Site $13(3,960 \mathrm{~m}$ a.s.1.) indeed has a high velocity third layer $\left(3.0 \mathrm{~km} \mathrm{~s}^{-1}\right)$, although the top of this layer lies at $13 \mathrm{~m}$ depth. The third layer probably represents bedrock, as exposed on the cliff fringing the river terrace.

Some seismic data fail to present unequivocal interpretation. The intermediate velocities $(1.5-1.7 \mathrm{~km}$ $\mathrm{s}^{-1}$ ) observed at 4,200-4,300 $\mathrm{m}$ a.s.l. indicate either an unfrozen saturated or a frozen sediment. The uppermost $4 \mathrm{~m}$ thick unfrozen layer at Sites 2, 5, and 17 possibly indicates degrading permafrost, because seasonal frost depth rarely exceeds $3 \mathrm{~m}$ in the study area (Wang et al., 2000; Matsuoka et al., 2005), whereas the accuracy of the measurement is $\pm 1 \mathrm{~m}$ (Ikeda, 2006). The top of frozen layer at Sites 4, 8, 11, 12, and $18(\leq 3 \mathrm{~m}$ deep) indicates the thawing front in August, so that whether the frozen layer is perennial or seasonal is also uncertain.

The borehole cores at Sites 9 and 10 show that the low velocities $\left(0.35-0.75 \mathrm{~km} \mathrm{~s}^{-1}\right)$ correspond to unsaturated and unconsolidated (i.e., unfrozen) sediments (Table 1). In addition, the second layer (1.7 $\mathrm{km} \mathrm{s}^{-1}$ ) lying below a depth of about $3 \mathrm{~m}$ at Site 10 does not correspond to a frozen layer but an unfrozen saturated layer.

\subsection{Results and interpretation of geoelectrical sounding}

The apparent DC resistivity increases from the ground surface downward at all sites (Fig. 8). The following downward decrease in resistivity results in a convex upward curve at eight sites (Sites 2, 4, 5, 6, 8, 9, 10, and 11). At Sites 9 and 10, the decreasing trend changes to slightly increasing or constant trend at the end. The increasing trend at Sites 7 and 12 declines and becomes constant. Resistivity continues to increase at Site 13.

In general, electrical resistivity in ground increases when ground temperature falls below $0{ }^{\circ} \mathrm{C}$ because of a decrease in liquid water content (e.g., Hoekstra and McNeill, 1973). Thus, assuming homogeneous water content in the ground, the observed increase in resistivity would indicate presence of a frozen layer. However, groundwater level and material composition often lead to vertically variable water content, so that resistivity stratigraphy should carefully be interpreted using other information (e.g., Ikeda, 2006).

All the uppermost resistivity layers showing low resistivity of 16-380 $\Omega \mathrm{m}$ are thinner than two meters (Table 1). The layers correspond to loess and/or organic soil. The second resistivity layers (150-2,200 $\Omega \mathrm{m})$ mainly consist of gravels, as revealed by the excavated pits and terrace outcrops. Thus, the downward increase in resistivity at a shallow depth probably corresponds to the difference in grain size distribution between the uppermost layer rich in fine-grained material and the gravel-rich underlying layer.

At Sites 2, 4, 5, and 8, the most resistant (650-1,100 $\Omega \mathrm{m})$ layer corresponds to a frozen sediment indicated by the seismic sounding (Table 1). The thickness of the frozen ground is estimated to be $27 \mathrm{~m}$ at Site 2, $10 \mathrm{~m}$ at Site 4, $26 \mathrm{~m}$ at Site 5, and $29 \mathrm{~m}$ at Site 8. In contrast, the resistivity at Sites 7, 9, and 10 decreases toward the third layer (30-140 $\Omega \mathrm{m})$. This layer corresponds to $\mathrm{P}$-wave velocity layer of $1.5-1.8 \mathrm{~km} \mathrm{~s}^{-1}$ indicating groundwater level. At these three sites, permafrost is probably absent below the groundwater level because the low resistivity layer(s) is thicker than several tens of meters. The bedrock indicated by the seismic profile at Site 13 has higher resistivity $(500 \Omega \mathrm{m})$ than the overlying unfrozen sediments.

The most resistant layer at Sites $6(1,000 \Omega \mathrm{m})$ and $12(2,200 \Omega \mathrm{m})$ is unfrozen because the P-wave velocity $\left(<0.8 \mathrm{~km} \mathrm{~s}^{-1}\right)$ at the depth is much lower than that of the frozen sediment, whereas the less resistant underlying layer (450-600 $\Omega \mathrm{m})$ corresponds to permafrost indicated by the P-wave velocity higher than $2 \mathrm{~km} \mathrm{~s}^{-1}$ (Table 1). At Site 6, the frozen sediment at 10-21 $\mathrm{m}$ depth is relict permafrost. The thin (c. $1 \mathrm{~m}$ ) third layer with low resistivity $(140 \Omega \mathrm{m})$ indicates thin aquifer above the frost table. The resistivity stratigraphy at Site 11 shows no high resistivity layer above 15 $\mathrm{m}$ depth, probably showing that the frozen sediment sounded by the seismic method was quite thin and seasonally formed. A high resistivity layer $(840 \Omega \mathrm{m})$ at 15-44 $\mathrm{m}$ depth indicates possible presence of relict permafrost.

\subsection{Results and interpretation of thermal monitoring}

Figures 9 and 10 display annual variations in daily mean surface temperatures in 2003-2004 and 20052006, respectively. Lack of a figure for 2004-2005 is due to missing data at six out of the eight sites caused by battery leaking in wet soils probably after heavy rainfalls in July 2005.

A comparison between different sites shows that elevation affects ground surface temperatures, whereas other factors such as latitude, snow cover, 

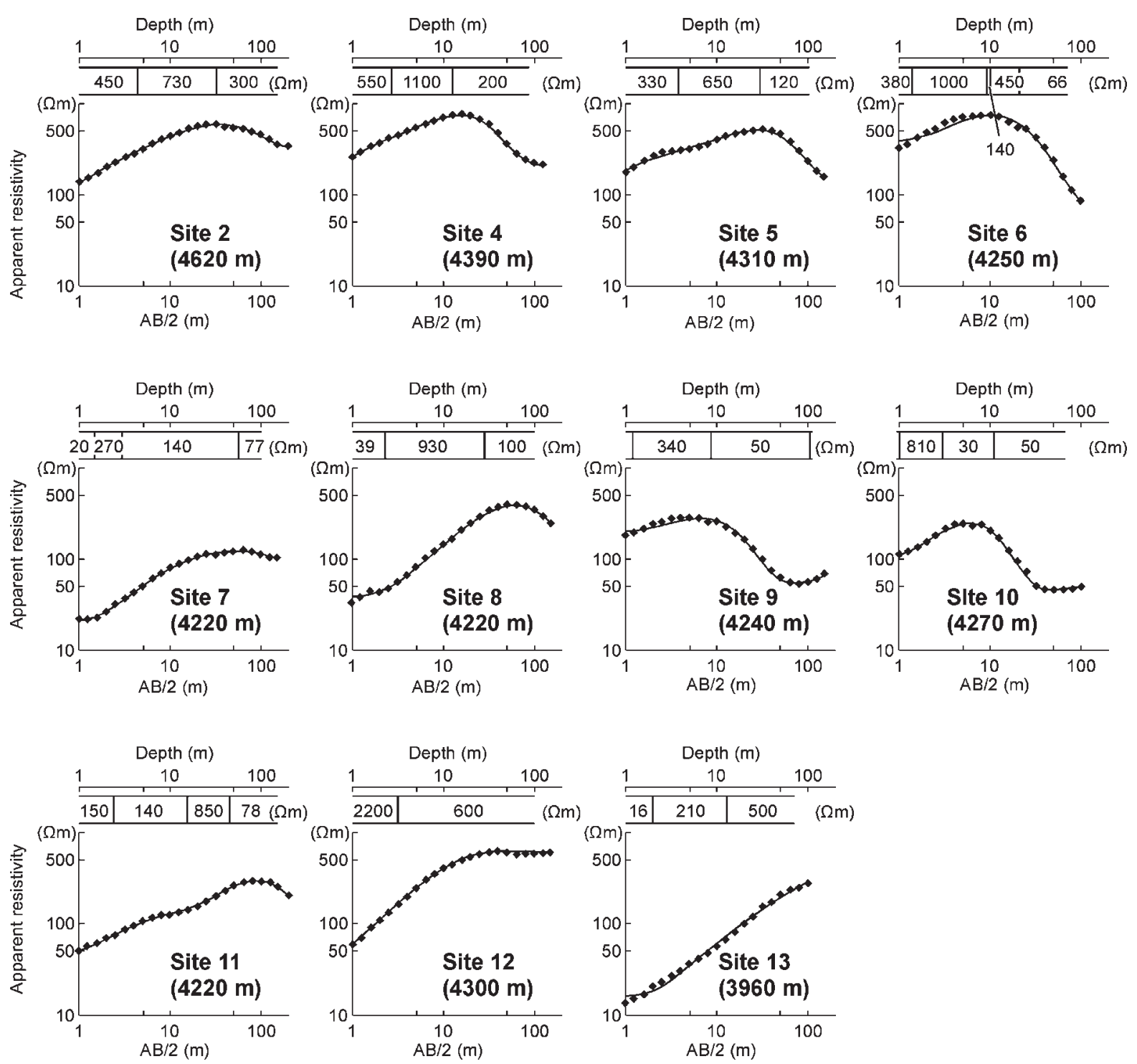

Fig. 8 Apparent electrical DC resistivity curves and calculated resistivities. Note that the calculated resistivities of the first layer thinner than $1 \mathrm{~m}$ are not displayed.

and inversion of air temperature appear to also control the temperatures especially above $4,200 \mathrm{~m}$ a.s.1. More southward (i.e., warm) location of higher sites probably diminished the difference in temperature between different elevations. In the study area, snow cover insulating ground surface was mostly lacking which was indicated by large daily variations in ground surface temperatures and low precipitation (see also Section 3.2.2). The highest two sites (Sites 1 and 3) were, however, covered by snow enough to decrease daily variations of temperature in late 2005 . As a result, temperatures of Sites 1 and 3 were much higher than those of sites on 4,200-4,300 $\mathrm{m}$ a.s.1. (Sites 5, 6, 9, 10 and 11) during the snow-covered period (Fig. 10).

MASTs in 2003-2004 at eight sites varied from $5.7{ }^{\circ} \mathrm{C}$ to $-0.8{ }^{\circ} \mathrm{C}$ with increasing elevation (Table
1 and Fig. 11A). The overall relation is given by MAST $=-4.5 H+20.2$, where $H$ is elevation in $\mathrm{km}$. However, MASTs were similar between Sites 1, 3, and 4 and between Sites 13 and 14 despite the significant difference in elevation (200-400 m). This was mainly due to strong inversion of temperatures in winter, which resulted in the similar daily mean temperatures in winter except at the lowermost Site 15 (Fig. 9). For example, Fig. 12 illustrates inversion of night temperatures between 4,200 $\mathrm{m}$ and 4,800 $\mathrm{m}$ a.s.1. and between 3,800 $\mathrm{m}$ and $4,200 \mathrm{~m}$ a.s.1. in mid December 2003. This is probably because radiative cooling is more prominent in the broad basins (Sites 11 and 14) than hilly locations (Sites 1, 3, 4, and 13). In addition, cloudy/foggy conditions in winter daytime may contribute to lower temperatures at lower locations near the foot of hills 


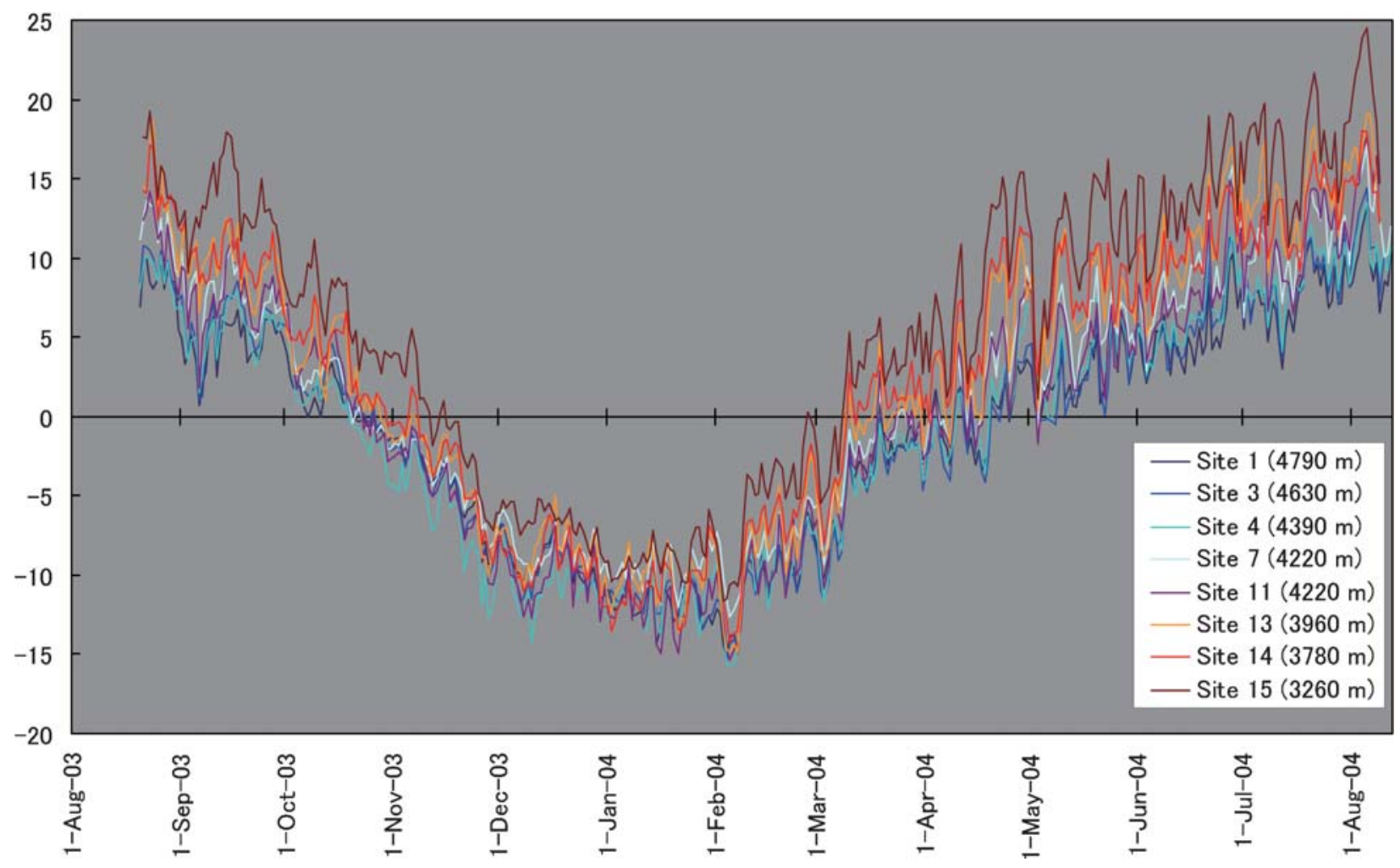

Fig. 9 Annual variation in mean daily surface temperature in 2003-2004.

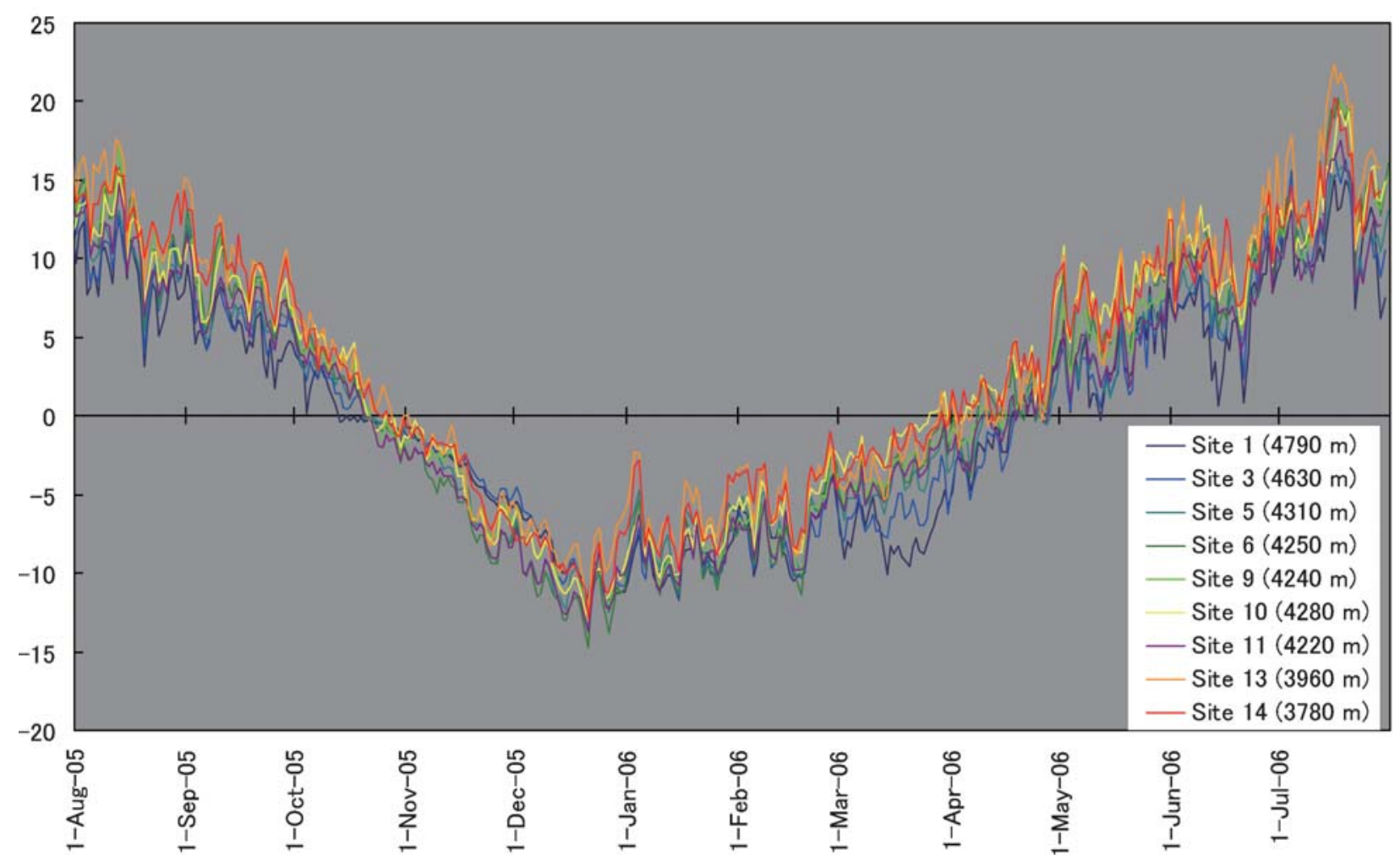

Fig. 10 Annual variation in mean daily surface temperature in 2005-2006. 

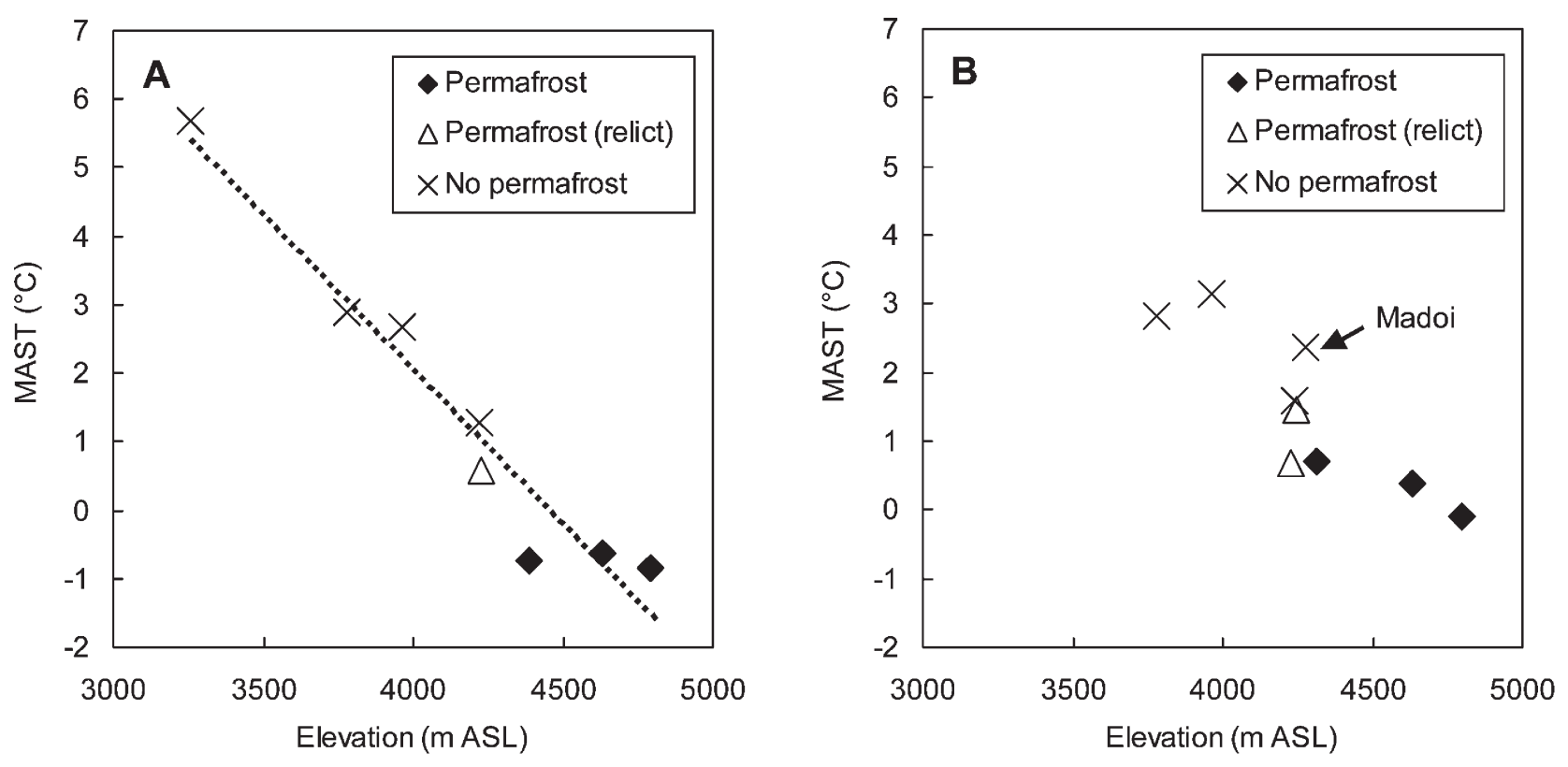

Fig. 11 Altitudinal variation in the mean annual surface temperature (MAST) in 2003-2004 (A) and 2005-2006 (B). The regression line in A is expressed by MAST $=-4.5 H+20.2$, where $H$ is elevation in $\mathrm{km}$.

(Sites 4 and 7) than higher locations near the crests of hills (Sites 1 and 3) on the plateau. In particular, the smallest daily variation in temperature at Site 7 may be maintained by exceptionally cloudy/foggy conditions near a lake (Fig. 12B).

The MAST in 2005-2006 was poorly correlated with elevation (Table 1 and Fig. 11B). This is partly because thick snow cover at Sites 1 and 3 significantly prevented cooling. In addition, MAST at the Madoi observatory (Site 10) was much higher than the surrounding sites. The relatively high temperatures at Madoi throughout the year (Fig. 10) indicated heat island by human activity of the village.

The results of geophysical soundings show that the boundary MAST for presence of contemporary permafrost is around $1{ }^{\circ} \mathrm{C}$ (Fig. 11). MASTs close to the melting point between $4,300 \mathrm{~m}$ and $4,800 \mathrm{~m}$ a.s.1. indicate that permafrost in the source area is quite warm even near the highest location because of the inversion of air temperature and relatively snow-rich condition near the southern divide.

\subsection{Mapping permafrost}

Permafrost distribution fitted to the sounding results was mapped by means of GIS. In the eastern Asia, the elevation of the lower limit of permafrost, $H_{\mathrm{P}}$, increases both southward with the general increase in temperature and westward with decrease in cloud cover (e.g., Cheng, 1983). Using the boundary elevations of arid continental Asian mountains in Matsuoka (2003), the overall trend of latitudinal variation is expressed by $H_{\mathrm{P}}(\mathrm{m}$ a.s. 1.$)=9600-150 L_{\mathrm{N}}\left(\mathrm{R}^{2}=0.89\right)$, where $L_{\mathrm{N}}$ is the latitude $\left({ }^{\circ} \mathrm{N}\right)$. When the boundary elevations are normalized at the same latitude using the lapse rate $150 \mathrm{~m}$ per degree of latitude, the longitudinal lapse rate is estimated to be $30 \mathrm{~m}$ per degree of longitude. The permafrost distribution fitting the sounding results was calculated using the lapse rates of the permafrost boundary. When the distribution most successfully meets the sounding results, the boundary elevation for the contemporary permafrost (i.e. permafrost without talik) is 4,270 m a.s.1. at Madoi (Fig. 13).

Groundwater hydrology is only susceptible to permafrost in the alluvial plains in the source area, because the surrounding hills and mountains mostly lack unconsolidated layers thicker than $1 \mathrm{~m}$ below the surface. The area having 'perennially frozen sediment' is estimated to be $13,600 \mathrm{~km}^{2}$ in the source area and $14,800 \mathrm{~km}^{2}$ in the whole Yellow River Basin including a tributary flowing from the Qilian Mountains (Fig. 13). In addition, distribution pattern including sites underlain by relict permafrost requires a boundary elevation $80 \mathrm{~m}$ lower than that of the contemporary permafrost (Fig. 14). This slight shift in elevation corresponds to $3,000 \mathrm{~km}^{2}$ difference in area having perennially frozen sediment in the source area. Since the elevations widely lie under transitional conditions between permafrost and seasonal frost environments, the source area currently faces a rapid loss of the permafrost area under recent warming trend. Further $80 \mathrm{~m}$ rise in boundary elevation will degrade perennially frozen sediment in additional $4,000 \mathrm{~km}^{2}$ area. 

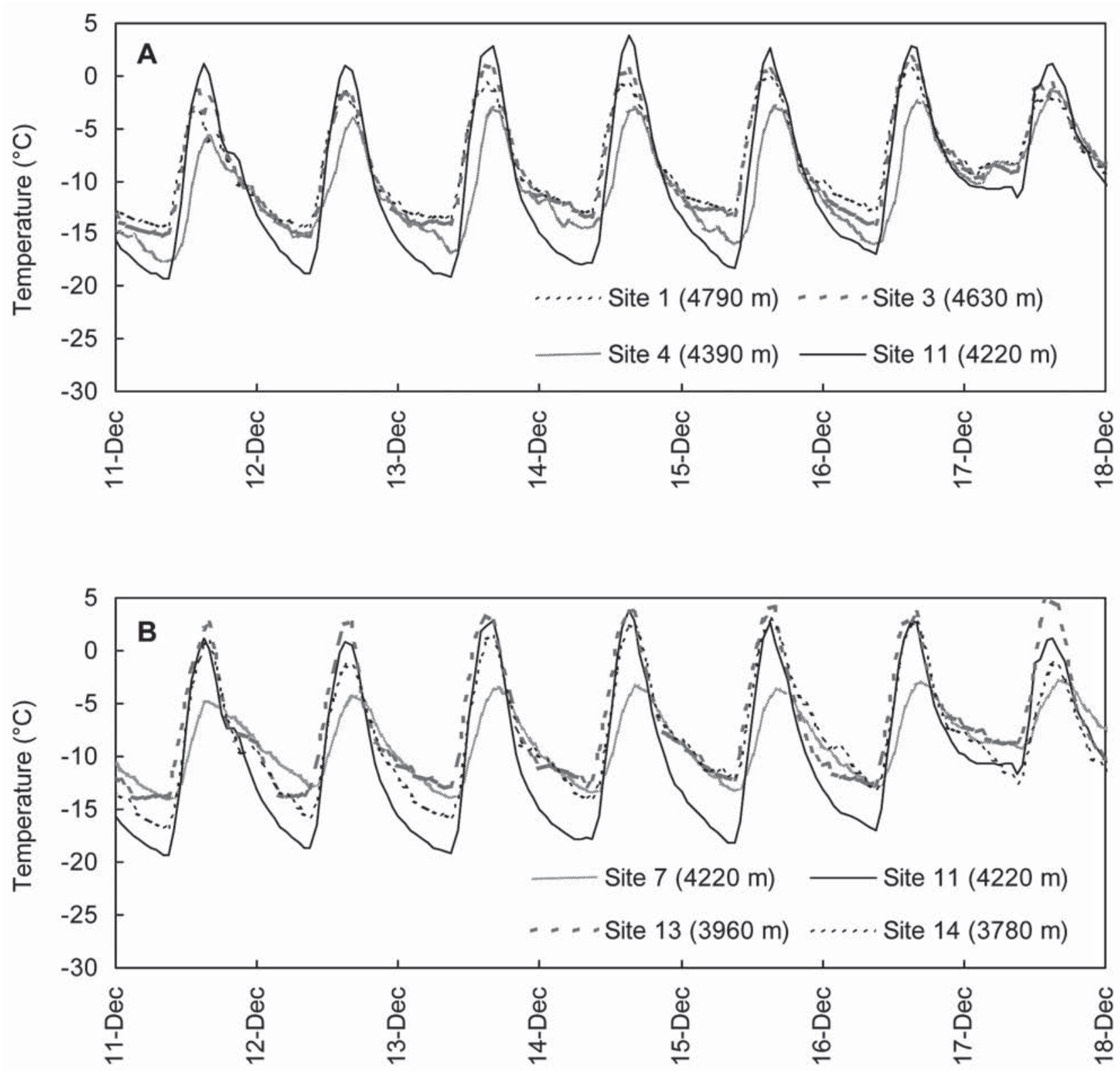

Fig. 12 Typical diurnal variations in ground surface temperature in December 2003 at 7 sites, showing altitudinal inversion in temperature. (A) Temperatures at sites above 4,220 m a.s.l. (B) Temperatures at sites below 4,220 $\mathrm{m}$ a.s.1. Site 7 (4,220 $\mathrm{m}$ a.s.l.) is located near a lake.

\section{Modeling of past and future permafrost evolution}

In this section, numerical approach is used to evaluate the temporal evolution of the permafrost. Earlier studies indicated wide distribution of permafrost in the alluvial planes of the upper Yellow River Basin in the early 1980 s, although the original thickness and the temporal evolution were not clear. Longterm meteorological records suggest that the study area experienced gradual warming in air temperature during the last two decades, which resulted in the degradation of permafrost. To answer the question whether this degradation relates to the desertification (see Section 3.1) or not, we estimate the time scale of the degradation. We made forward calculations of the permafrost thawing with given initial conditions, using the ground surface temperatures recorded in this study and the long-term records of air temperature at Madoi. Our aim in modeling is to constrain the history of permafrost degradation in the region, and to examine if this process has the preferable time scale to the observed desertification in the area.

\subsection{Model settings}

Since our interest is in the response of the ground temperature profile to warming climate, the problem 


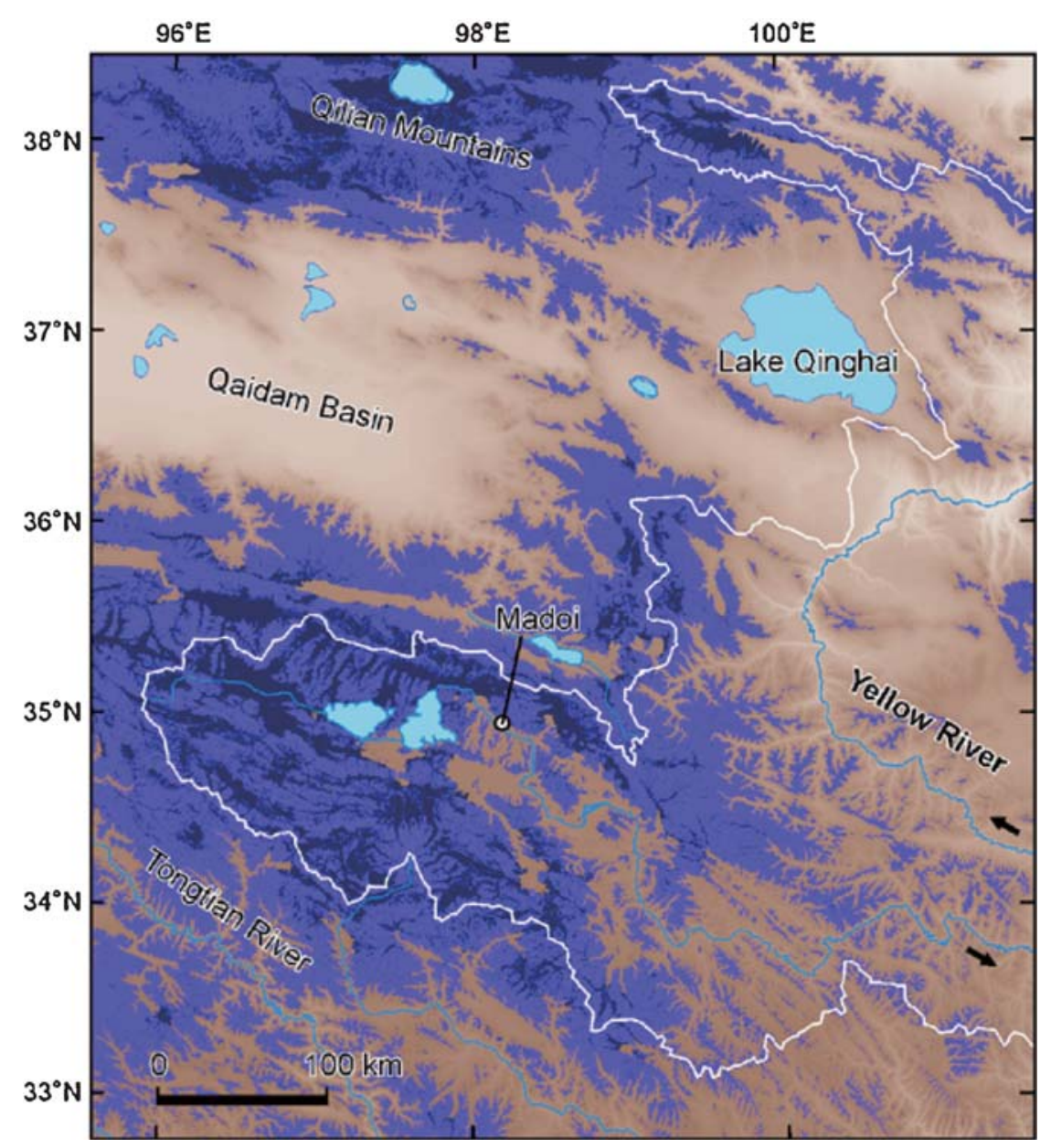

Fig. 13 Permafrost distribution in the eastern Qinghai Province. Dark blue indicates presence of permafrost in alluvial plains (i.e. sediment is frozen), whereas light blue indicates presence of permafrost in hills and mountains (i.e. bedrock is frozen). White line is the divide of the Yellow River.

can be set as a one-dimensional heat conduction model, driven by ground surface temperature at the upper boundary (Dirichlet-type boundary condition) and geothermal heat flux at the lower boundary (Neumanntype boundary condition). Atmospheric part is not included in this model, i.e., energy balance at the surface is not solved, but surface temperature is directly given as a boundary condition instead. The ground temperature variation is calculated by solving the following heat conduction equation,

$$
\frac{d T}{d t}=\kappa \frac{\partial}{\partial x}\left(\frac{\partial T}{\partial x}\right)
$$

where $T$ is temperature, $t$ time, $x$ location, and $\kappa$ thermal diffusivity represented as a fraction of thermal conductivity and volumetric heat capacity.

Numerically, Multipoint Adams-Bashforth (MAB) method was used to solve the equations; since this is an explicit finite difference scheme, grid and time spacing should satisfy the stability condition. In this study, a spatial grid and a time step are set to $0.2 \mathrm{~m}$ and 1 hour, respectively. The effect of the latent heat in phase change is taken into consideration using an additional apparent heat capacity during freezing/thawing, the value of which is dependent on the soil water content (Lunardini, 1991). Soil water content is set to $10 \%$ in this calculation according to the measured value. The thermal properties of soil, which should have different values for frozen and unfrozen soils, are prescribed as follows.

\begin{tabular}{lll}
\multicolumn{3}{l}{ Thermal conductivity } \\
\hline Organic layer & Frozen: $1.5 \mathrm{~W} / \mathrm{m} \cdot \mathrm{K}$ & Unfrozen: $0.9 \mathrm{~W} / \mathrm{m} \cdot \mathrm{K}$ \\
Sandy soil+ gravel & Frozen: $1.7 \mathrm{~W} / \mathrm{m} \cdot \mathrm{K}$ & Unfrozen: $1.2 \mathrm{~W} / \mathrm{m} \cdot \mathrm{K}$ \\
Bedrock & Frozen: $3.2 \mathrm{~W} / \mathrm{m} \cdot \mathrm{K}$ & Unfrozen: $2.5 \mathrm{~W} / \mathrm{m} \cdot \mathrm{K}$
\end{tabular}

Volumetric Heat capacity

All layers $\quad$ Frozen: $1.5 \times 10^{6} \mathrm{~J} / \mathrm{m}^{3} \mathrm{~K} \quad$ Unfrozen: $2.0 \times 10^{6} \mathrm{~J} / \mathrm{m}^{3} \mathrm{~K}$ 


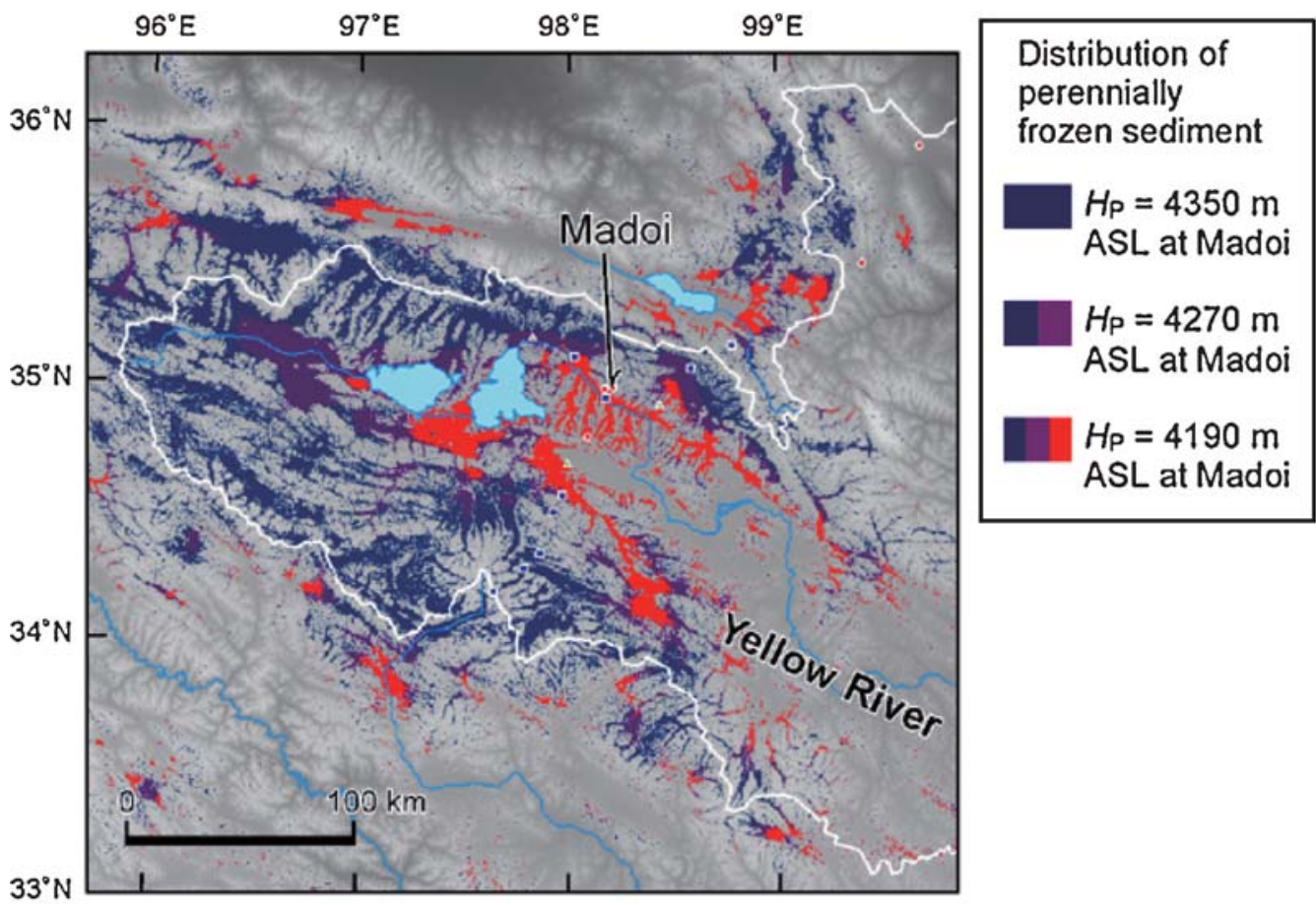

Fig. 14 Distribution of perennially frozen sediment in the source area for three different elevations of the lower limit of permafrost $\left(H_{\mathrm{P}}\right)$. The present $H_{\mathrm{P}}$ is $4,270 \mathrm{~m}$ a.s.l. at Madoi.

Based on the in-situ observation, three layers are defined with respect to soil properties. The first layer is top $0.2 \mathrm{~m}$ of an organic layer, which has low thermal conductivities. The second layer is sandy soil with gravels down to $10 \mathrm{~m}$ deep, and the third layer underlying bedrock.

\subsection{Initial and boundary conditions}

Although the initial temperature profile is necessary for calculations, there is no information about it. We therefore prescribed two end-member cases; one is the equilibrium temperature profile with geothermal heat flux for the whole soil layer, the other is $0{ }^{\circ} \mathrm{C}$ profile for the entire permafrost part and again the equilibrium temperature gradient underneath. The former condition corresponds to stable (i.e., cold) permafrost under the long-term appropriate climate condition, and the latter can be an analogue of warm permafrost case which is either exposed to warm surface condition $\left(\sim 0{ }^{\circ} \mathrm{C}\right.$ surface $)$ for long time or affected by ground water system. The real case should be between these two extreme conditions. For both types of the initial temperature profiles, three initial thicknesses of the permafrost are assumed; $15 \mathrm{~m}, 25 \mathrm{~m}$, and $50 \mathrm{~m}$. In total, the experiments were carried out for six initial conditions.

For the upper boundary condition, the seasonal variation in the ground surface temperature recorded at Madoi was used, with an offset value to adjust mean annual values for each modeled year. It is based on the assumption that the pattern of the seasonal variation is independent of the changing climate conditions, such as long-term warming. The offset is prescribed that MAAT has linearly increased by $2{ }^{\circ} \mathrm{C}$ within the last 50 years. After 50 years, the offset is kept to be constant, so that mean annual surface temperature should be the same as the present value. Given the positive annual mean ground surface temperature $\left(+1.0{ }^{\circ} \mathrm{C}\right)$, permafrost thaws after a certain period for all cases. The time required for thawing depends on the initial conditions (thickness and profile).

For the lower boundary, heat flux of $0.05 \mathrm{~W} \mathrm{~m}^{-2}$ is prescribed, which is reasonable for tectonically stable continental crust. The upper Yellow River Basin is generally located in such an inactive area, with a few exceptions of active fault zones. For the study area (Madoi and its surrounding area), this assumption is considered to be reasonable.

\subsection{Results and perspectives}

Temporal variation of the temperature profiles are shown for the six initial conditions (Fig. 15); three initial thicknesses each with two cases of initial profiles corresponding to cold (equilibrium-profile, indicated as (a) ) and warm $\left(0{ }^{\circ} \mathrm{C}\right.$-permafrost, as (b) $)$ conditions. The profiles are snap-shots at the end of summer periods, showing the seasonally thawing layer associated with the warm temperature at the surface. The upper 10 


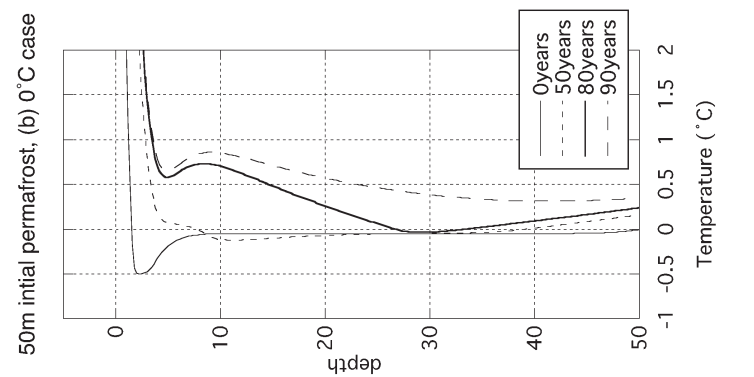

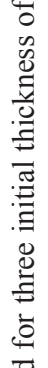

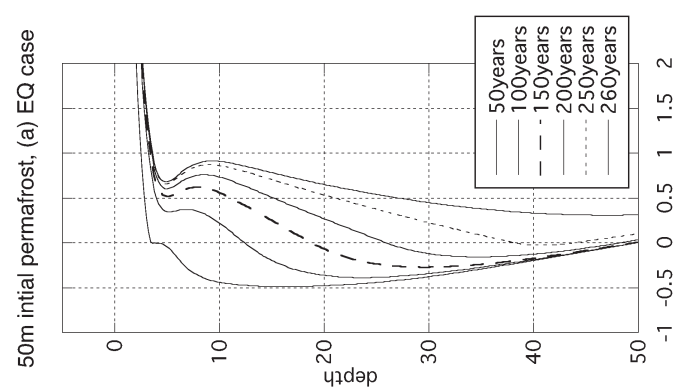

: $\frac{\overline{0}}{\frac{0}{5}}$
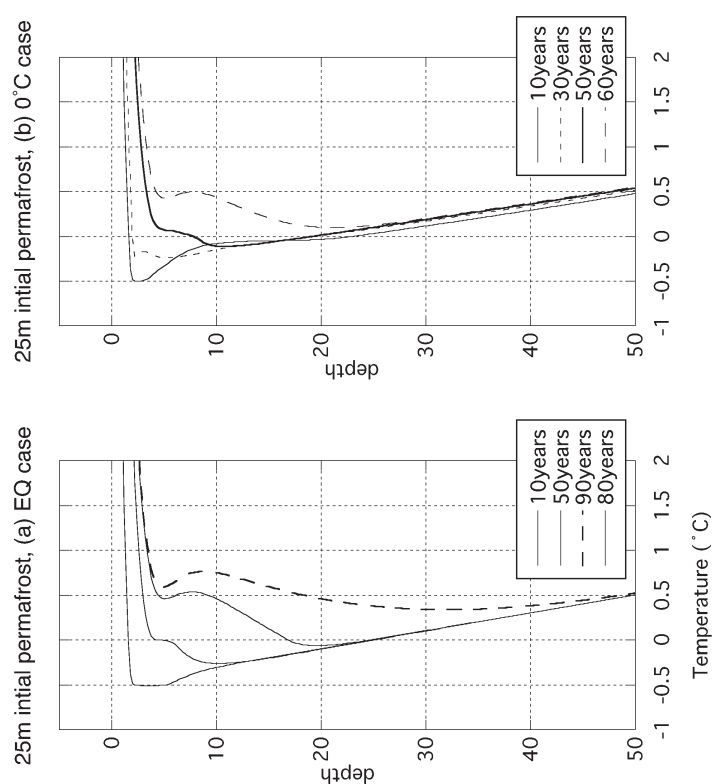

范

สิ

.을

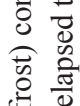

를

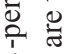

¿ :

E

ลิ

อ

羟

(ब)

힐

音

के

항

긍

(ङ) त्

घं क्ष

: के

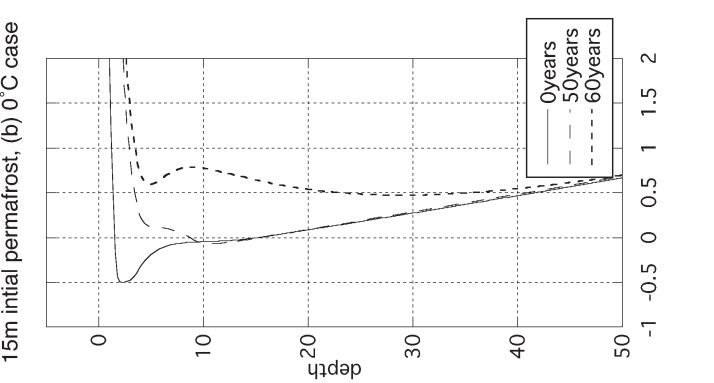

ठี้

晃

寻 등

a

常

क छ

를

है

要

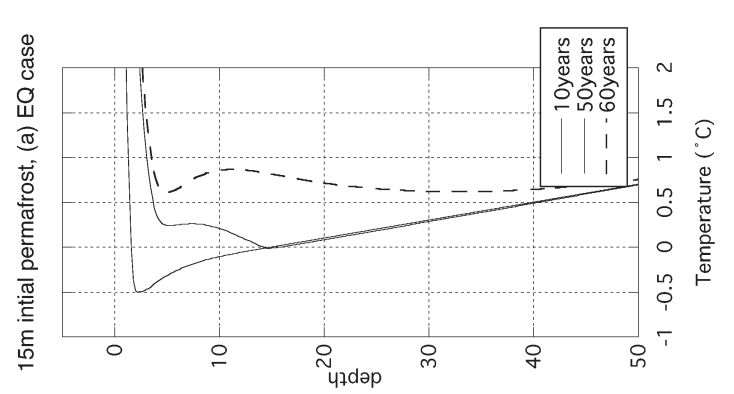

荥 
to $15 \mathrm{~m}$ is subject to the penetration of the seasonal temperature variation, which is reasonable in terms of the skin depth and also the phase delay (Turcotte and Schubert, 1982).

According to this calculation, time required for complete thaw is as follows.

\begin{tabular}{lllr} 
Initial thickness & $15 \mathrm{~m}$ & $25 \mathrm{~m}$ & \multicolumn{1}{l}{$50 \mathrm{~m}$} \\
\hline a) Cold condition & 52 years & 85 years & 253 years \\
b) Warm condition $\left(0^{\circ} \mathrm{C}\right)$ & 47 years & 59 years & 83 years
\end{tabular}

The results show the strong dependence of the time required for thaw to both the initial thickness and the type of temperature profile. Shallow (c. $15 \mathrm{~m}$ ) permafrost can completely degrade within approximately 50 years, which is not dependent on the initial temperature profiles. Thicker permafrost takes much longer time to thaw, even started with warm condition. Considering that the seasonal variation penetrates as deep as 10-15 $\mathrm{m}$, we conclude that even very shallow permafrost takes about 50 years for degrading process.

If the original thickness of permafrost was relatively thick, about $10 \mathrm{~m}$ of supra-permafrost talik can reasonably exist in the present-day condition. Thus, the relict permafrost can be still found in the region, although it is considered to be thin and warm.

The previous reports on permafrost distribution (e.g., Zhou et al., 2000) are therefore consistent only if the original thickness of permafrost in the region is relatively shallow before 1980s. In such a case, the time scale of the permafrost degradation can be comparable to that of reported desertification (lake shrinkage, vegetation degradation, etc.) of the plateau, which hints the causal relationship.

\section{References}

Böhner, J. and Lehmkuhl, F. (2005) Environmental change modelling for Central and High Asia: Pleistocene, present and future scenarios. Boreas, 34, p.220-231.

Cheng, G. (1983) Vertical and horizontal zontaion of high-altitude permafrost. Proceedings of the fourth International Conference on Permafrost. National Academy Press, Washington, p.136-141.

Feng, J.F., Wang, T. and Xie, C. (2006) Ecoenvironmental degradation in the source region of the Yellow River, Northeast QinghaiXizang Plateau. Environmental Monitoring and Assessment, 122, p.125-143.

Harris, C., Vonder Mühll, D., Isaksen, K., Haeberli, W., Sollid, J. L., King, L., Holmlund, P., Dramis, F., Guglielmin, M. and Palacios, D. (2003) Warming permafrost in European mountains. Global and Planetary Change, 39, p.215-225.
Hoekstra, P. and McNeill, D. (1973) Electromagnetic probing of permafrost. Proceedings of the Second International Conference on Permafrost. National Academy of Sciences, Washington, p. 517-526.

Hunter, J.A.M. (1973) The application of shallow seismic methods to mapping of frozen surficial materials. Proceedings of the Second International Conference on Permafrost. National Academy of Sciences, Washington, p.527-535.

Ikeda, A. (2006) Combination of conventional geophysical methods for sounding the composition of rock glaciers in the Swiss Alps. Permafrost and Periglacial Processes, 17, p.35-48.

Ikeda, A. and Matsuoka, N. (2002) Degradation of talus-derived rock glaciers in the Upper Engadin, Swiss Alps. Permafrost and Periglacial Processes, 13, p.145-161.

Ikeda, A., Matsuoka, N. and Sueyoshi, T. (2004) Permafrost survey in the source region of the Yellow River: a preliminary report. Seppyo, 66, p.235-239. (in Japanese)

Ikeda, A., Sueyoshi, T., Matsuoka, N., Ishii, T. and Uchida, Y. (2007) Permafrost sounding (2003$2005)$ in the source area of the Yellow River, Northeastern Tibet. Geographical Review of Japan, 80, p.63-75.

Jin, H., Li, S., Cheng, G., Wang, S. and Li, X. (2000) Permafrost and climatic change in China. Global and Planetary Change, 26, p.387-404.

Koefoed, O. (1979) Geosounding Principles, 1. Resistivity Sounding Measurements. Elsevier, Amsterdam, 276p.

Lachenbruch, A.H. and Marshall, B.V. (1986) Changing climate: geothermal evidence from permafrost in the Alaskan Arctic. Science, 234, p.689-696.

Lunardini, V.J. (1991) Heat transfer with freezing and thawing, Developments in geotechnical engineering 65. CREEL, Hanover, USA. Elsevier, Amsterdam, $49 \mathrm{p}$.

Lunardini, V.J. (1996) Climatic warming and the degradation of warm permafrost. Permafrost and Periglacial Processes, 7, p.311-320.

Matsuoka, N. (2003) Contemporary permafrost and periglaciation in Asian high mountains: an overview. Zeitschrift für Geomorphologie N.F. Suppl.-Bd., 130, p.145-166.

Matsuoka, N., Ikeda, A., Sueyoshi, T. and Ishii, T. (2004) Permafrost sounding (2003-2004) in the source area of the Yellow River, China. Annual Report of the Institute of Geoscience, University of Tsukuba, 30, p.33-38.

Matsuoka, N., Ikeda, A., Sueyoshi, T. and Ishii, T. (2005) Monitoring frozen ground (2004-2005) at Madoi in the source area of the Yellow River, China. Tsukuba Geoenvironmental Sciences, 1, p.39-44. 
Matsuoka, N., Ikeda, A., Sueyoshi, T. and Ishii, T. (2006) Frozen ground monitoring (2004-2006) in the source area of the Yellow River, China. Tsukuba Geoenvironmental Sciences, 2, p.25-30.

Milsom, J. (2003) Field Geophysics, 3rd ed. John Wiley \& Sons, Chichester, 232p.

Osterkamp, T.E. and Romanovsky, V.E. (1999) Evidence for warming and thawing of discontinuous permafrost in Alaska. Permafrost and Periglacial Processes, 10, p.17-37.

Owen, L.A., Finkel, R.C., Haizhou, M., Spencer, J.Q., Derbyshire, E., Barnard, P.L. and Caffee, M. W. (2003) Timing and style of Late Quaternary glaciation in northeastern Tibet. Geological Society of America Bulletin, 115, p.1356-1364.

Palmer, D. (1986) Refraction Seismics. Geophysical Press, London, 269p.

Peng, X., Wu, Q. and Tian, M. (2003) The effect of groundwater table lowering on ecological environment in the headwaters of the Yellow River. Journal of Glaciology and Geocryology, 25, p. 667671. (in Chinese with English abstract)

Sharkhuu, N. (1998) Trends of permafrost development in the Selenge River Basin, Mongolia. Proceedings of the Seventh International Conference on Permafrost. Centre d'études Nordiques, SainteFoy, p.979-985.

Spaans, E.J.A. and Baker, J.M. (1995) Examining the use of time domain reflectometry for measuring liquid water content in frozen soil. Water Resources and Research, 31, p.2917-2925.

Stein, J. and Kane, D.L. (1983) Monitoring the unfrozen water content of soil and snow using time domain reflectometry. Water Resources and Research, 19, p.1573-1584.

Turcotte, D.L. and Schubert, G. (1982) Geodynamics. John Wiley \& Sons, New York, 450p.

Wang, G., Qian, J., Cheng, G. and Lai, Y. (2001) Eco-environmental degradation and causal analysis in the source region of the Yellow River. Environmental Geology, 40, p.884-890.

Wang, J. and Derbyshire, E. (1987) Climatic geomorphology of the north-eastern part of the QinghaiXizang Plateau, People's Republic of China. Geographical Journal, 153, p.59-71.

Zhang, S., Wang, Y., Zhao, Y., Huang, Y., Li, Y., Shi, W. and Shang, X. (2004) Permafrost degradation and its environmental sequent in the source regions of the Yellow River. Journal of Glaciology and Geocryology, 26, p.1-6. (in Chinese with English abstract)

Zhang, T. (2005) Influence of the seasonal snow cover on the ground thermal regime: an overview. Reviews of Geophysics, 43, RG4002.

Zhou, Y., Guo, D., Qiu, G. and Cheng, G. (2000) Geocryology in China. Science Press, Beijing, 450p. (in Chinese)

Received December, 15, 2008

Accepted December, 19, 2008 


\section{黄河源流域の永久凍土および水文環境}

\section{松岡憲知・池田 敦・末吉哲雄・石井武政}

要 旨

チベット高原北東部に位置する黄河源流域に扔いて，永久凍土分布とその縮小を明らかにするために，2003年から 2006年にかけて凍土環境の調査を行った. まず標高 $3250 \sim 4800 \mathrm{~m}$ 間の 18 力所に执いて, 弾性波探査, 電気探査と地 温調査により永久凍土の有無を調べ，GISを用いて探査結果に最も合う永久凍土分布図を作成した。 また，マドオ測 候所（標高 $4273 \mathrm{~m} ） に て 2$ 年間, 気温, 地温 $(0 \sim 8 \mathrm{~m}$ 深), 降水量, 積雪深, 土㩙水分, 地下水位の連続観測を行い, 地中の熱打よび水文条件の季節変化について検討した。 さらに，地温プロファイルの数值シミュレーションによって， 観測されている気温変化（温暖化）によって，永久凍土がどの程度縮小しうるか検討した.

速い $\mathrm{P}$ 波伝播速度 $(>2 \mathrm{~km} / \mathrm{s}$ ) と相対的に高い電気比抵抗值（650 $1100 \Omega \mathrm{m} ）$ が地下浅い位置に検出された標高 $4300 \mathrm{~m}$ 以上の地点では, 厚さ $10 \sim 30 \mathrm{~m}$ の永久凍土層があると推定された。 一方, 標高 $4000 \mathrm{~m}$ 以下では堆積物全体が 遅いP波速度 $(<1 \mathrm{~km} / \mathrm{s})$ を示し, 永久凍土は存在しないと考えられる. 標高 $4200 \sim 4300 \mathrm{~m}$ にある広大な沖積低地では, 永久凍土は存在しないか，かなり縮小していた，年平均地表面温度（MAST）が負值となるのも $4300 \mathrm{~m}$ 以上で，元の 標高以上にのみ永久凍土が広範に分布すると予想された。測候所では季節的な凍結が深さ $2.6 \mathrm{~m}$ まで及んだ. 冬季, 積 雪をほとんど久くことが，厚い季節凍土層が形成される主因だろう。1980年代の文献には，測候所の地下に永久凍土 が存在するとされていたが, 深さ $4 \sim 8 \mathrm{~m}$ の地温は 2 年間にわたり $0^{\circ} \mathrm{C}$ を回っていた $\left(<4{ }^{\circ} \mathrm{C}\right) . \mathrm{MAST}$ の年々変化 が年平均気温の変化に従うとすると，標高 $4200 \sim 4300 \mathrm{~m}$ にある沖積低地で過去半世紀以内に，永久凍土が急激に縮 小したと考えられる。数值シミュレーションからも，薄い（<15 m) 永久凍土層であればその期間内に急激に縮小し うることが示された。近年の温暖化は，源流域に扔いて約 $3000 \mathrm{~km}^{2}$ に及ぶ沖積低地の永久凍土を縮小させていると推 定された。 